\title{
El estudio de las instituciones del gobierno colonial. Una aproximación etnográfica al juicio de residencia como ritual
}

The study of colonial government institutions. An ethnographic approach to the juicio de residencia as ritual

\section{Silvina Smietniansky}

\section{(2) OpenEdition}

Journals

\section{Electronic version}

URL: https://journals.openedition.org/corpusarchivos/910

DOI: 10.4000/corpusarchivos.910

ISSN: 1853-8037

\section{Publisher}

Diego Escolar

\section{Electronic reference}

Silvina Smietniansky, «El estudio de las instituciones del gobierno colonial. Una aproximación

etnográfica al juicio de residencia como ritual», Corpus [En línea], Vol 2, No 1 | 2012, Publicado el 30 junio 2012, consultado el 21 septiembre 2021. URL: http://journals.openedition.org/corpusarchivos/ 910 ; DOl: https://doi.org/10.4000/corpusarchivos.910

This text was automatically generated on 21 September 2021.

Licencia Creative Commons: Atribución-NoComercial 2.5 Argentina (CC BY-NC 2.5 AR) 


\title{
El estudio de las instituciones del gobierno colonial. Una aproximación etnográfica al juicio de residencia como ritual
}

\author{
The study of colonial government institutions. An ethnographic approach to the \\ juicio de residencia as ritual
}

Silvina Smietniansky

\section{EDITOR'S NOTE}

Fecha de recepción del original: 03/04/2012. Fecha de aceptación para publicación:

$21 / 06 / 2012$

\section{Introducción}

1 En 2005 iniciamos la exploración de un extenso expediente elaborado en el marco de un juicio de residencia que tuvo lugar en la gobernación del Tucumán a fines de 1775 y comienzos de 1776. Se trataba de la residencia seguida a don Juan Manuel Fernández Campero quien estuvo al mando de la provincia entre 1764 y 1769. Esa clase de procesos judiciales estaba destinada a evaluar la labor de los funcionarios públicos al finalizar sus mandatos y a mejorar las instituciones de gobierno. En realidad, ese corpus documental ya había sido examen de un trabajo previo (Lorandi y Smietniansky 2004), pero ahora -en una segunda vuelta- nos aproximábamos a él con una pregunta muy simple: ¿la celebración de dicha residencia podía ser considerada y analizada bajo el concepto de ritual? Este primer interrogante organizó de ahí en más las directrices de nuestra búsqueda bibliográfica: 1) bibliografía referida a la historia de las instituciones coloniales, en particular, de las residencias; 2) literatura sobre historia colonial que abordara el 
vínculo entre ritual y poder, dado que estábamos tratando con una institución del gobierno colonial y pretendíamos analizarla en términos de un ritual; y 3) aquel campo de la producción antropológica en que se debatían y formulaban las teorías sobre el ritual.

2 A partir de la articulación, mediada por el examen de las fuentes, entre esos tres campos de investigación y producción bibliográfica (los cuales serán retomados más adelante) que en principio pueden resultar distantes entre sí, surgió nuestro problema de investigación, contextuado en la gobernación del Tucumán en la segunda mitad del siglo XVIII. Las residencias delimitaron el recorte institucional en el cual interesaba explorar bajo una aproximación etnográfica el vínculo entre ritual y poder, según era significado por los propios actores del mundo colonial. ${ }^{1}$ Lo que podríamos denominar algo así como "la perspectiva etnográfica del ritual" a partir de la cual abordamos la institución de las residencias resultó sumamente fértil puesto que dirigió nuestra mirada sobre aspectos de este proceso judicial que previamente no habíamos tomado en cuenta y que tampoco resultan objeto de estudio por parte de la historia de corte más institucional -con la cual compartimos el interés por describir y analizar los aspectos formales de las residencias. Esa otra aproximación, signada por el enfoque etnográfico y las teorías antropológicas sobre el ritual, contribuyó a interrogar la fuente, elaborar preguntas y tejer interpretaciones que descubren en la residencia algo más que una instancia jurídica de control sobre el poder local. Señalan el potencial de este acontecimiento para construir el orden social, ejercer el poder, convertirse en un campo de disputa política, imponer una forma diversa de experimentar el tiempo - un tiempo extraordinario que perturba los ritmos locales $-\mathrm{y}$ construir la historia a través de la elaboración de extensos expedientes.

3 Años después de examinar una y otra vez el expediete resultante de la residencia a Campero, iniciamos la exploración de una nueva residencia para probar, discutir y ampliar el modelo de análisis que elaboramos en base a ese primer caso. Se trata de la residencia instruida al gobernador don Juan Victorino Martínez de Tineo que tuvo lugar a fines de 1763 y comienzos de 1764. El registro documental que presentamos constituye un extracto del expediente de dicha residencia y este artículo contextúa y acompaña la lectura del mismo.

En las siguientes páginas nuestro interés se orienta a mostrar y reflexionar sobre las ventajas y otras facetas que nos permite descubrir el análisis de la residencia a partir del concepto de ritual y de una aproximación etnográfica al estudio de materiales de archivo. En ese recorrido el corpus documental resultante de la residencia a Tineo nos ayuda a ejemplificar en qué consiste esa otra forma de pensar e interrogar un mismo corpus documental. Para ello, en lo que sigue, estructuramos el artículo en tres partes. En una primera parte, interesa caracterizar la institución de las residencias -en particular, las instruidas a los gobernadores pues allí focaliza nuestro trabajo y de eso trata la fuente-: sus raíces históricas, sus objetivos, los actores involucrados, la forma que adoptaba la celebración de una residencia, entre otros aspectos. Y junto con ello también habremos de contextualizar y comentar el expediente objeto de examen. En segundo lugar, exponemos el marco analítico elaborado desde el cual nos aproximamos al estudio de esta institución, indicando de qué manera diversas ramas de la historia y de la antropología han confluido para elaborar un problema de investigación y direccionar el examen de las fuentes coloniales. Por último, considerando el enfoque propuesto, tomando como ejemplo el documento transcripto y recuperando nuestros trabajos anteriores, buscaremos señalar y reflexionar sobre las posibles líneas de investigación que abre esta perspectiva y sobre 
porqué entendemos que la misma contribuye a enriquecer el conocimiento que tenemos sobre las residencias.

\section{Residencias: institución, acontecimiento y fuente}

El juicio de residencia constituía un procedimiento jurídico-administrativo ordenado por la Corona que respondía a dos objetivos. Por un lado, como referíamos, fiscalizar los comportamientos de los funcionarios de gobierno una vez que concluyeran sus mandatos y sancionarlos en caso de que no hubieran cumplido con sus funciones; y por otro lado, recabar información sobre las falencias de la administración pública en Indias con vistas a formular medidas para mejorar su funcionamiento (Mariluz Urquijo 1952). Este mecanismo orientado a enmendar y limitar la arbitrariedad de los funcionarios públicos fue incorporado en las Siete Partidas a mediados del siglo XIII, lo que resulta lógico en el marco de un incipiente proceso en que el poder regio procuraba fortalecerse en los territorios hispanos (González Alonso 1978). El traslado de las residencias a las Indias junto con otros dispositivos de control como eran las visitas y pesquisas- en el contexto de la expansión del Imperio español, se vio motivado por ese mismo interés de controlar el accionar de funcionarios públicos y de reafirmar el poder de la Corona. El desarrollo de esta institución en los nuevos dominios se sentó en principio sobre el modelo metropolitano y la legislación castellana de la época, aunque posteriormente se iría adaptando a unos territorios distintos y a una mayor variedad de funcionarios que eran sometidos a la pesquisa, otorgando a la institución un carácter más flexible. ${ }^{3}$ Desde los virreyes y oidores de audiencia hasta los cabildantes debían ser residenciados una vez que hubieran finalizado su mandato para evaluar la conducta seguida durante la gestión de gobierno y habilitarlos a ejercer nuevos cargos.

El juicio de residencia debía llevarse a cabo en la jurisdicción donde el funcionario había ejercido su cargo y tenía una duración de sesenta días; en ese lapso de tiempo el residenciado debía permanecer (residir) en dicho lugar -de allí el término residencia(Mariluz Urquijo 1952). Se componía de dos etapas centrales, la pesquisa secreta y la pesquisa pública. En la primera parte el juez interrogaba a una serie de testigos que declaraban en forma confidencial sobre cuestiones atinentes a la conducta y la actuación del funcionario que estaba siendo residenciado. El magistrado también tenía competencia para solicitar informes a otros organismos, examinar documentación oficial, visitar la cárcel y las instalaciones de gobierno y recibir denuncias anónimas. En esta instancia el residenciado aún no prestaba declaración y el testimonio de los testigos constituía la prueba más significativa. En función de los datos resultantes el magistrado imputaba los cargos contra el residenciado y luego este procedía con su defensa. En la pesquisa pública la investigación se veía promovida por los particulares, quienes tenían derecho a presentar denuncias contra el funcionario procesado, con motivo de haberse vistos perjudicados por este o de estar en conocimiento de que obró mal con respecto a otras personas. El riesgo que corrían los denunciantes era que debían pagar las costas del juicio si las acusaciones resultaban infundadas. Finalmente, el juez dictaba la sentencia. Puesto que su comisión lo habilitaba sólo a declarar sobre la buena o mala conducta del funcionario procesado, no tenía competencia para intervenir en juicios pendientes o volver sobre causas ya juzgadas. En general, las penas impuestas fueron multas de variado monto, inhabilitación perpetua o temporaria. 
7 Nuestro trabajo de investigación se ha centrado en el examen de dos expedientes resultantes de sendos juicios de residencia instruidos a gobernadores del Tucumán en la segunda mitad del siglo XVIII. Se trata de la residencia instruida al gobernador Juan Martínez de Tineo en 1763-1764, cuyo mandato se extendió entre 1749 y 1754, y del proceso que posteriormente le fue seguido a Juan Manuel Fernández Campero en 1775-1776, que estuvo a cargo de la gobernación en 1764-1769. Es importante notar que cada uno de estos juicios también se encargó de juzgar la labor de todos aquellos que ocuparon cargos en los cabildos del Tucumán durante los mandatos de los respectivos gobernadores.

8 Esto último no es un dato menor si consideramos la significación que adquirieron los cabildos en la vida política, económica y social del Tucumán colonial y el grado de autonomía que lograron las élites en esta región. Desde los primeros esfuerzos puestos en la exploración y colonización de estas tierras vemos a los feudatarios de los nuevos dominios desenvolverse holgadamente al negociar la adquisición de encomiendas de indios y mercedes de tierras (Presta 2000). Con el tiempo, las fusiones de las primeras familias de conquistadores y sus descendientes con los inmigrantes españoles que sucesivamente arribaban a estas tierras, se asentaron en alianzas comerciales, políticas y matrimoniales, y fueron constituyendo una élite local cuya trama monopolizó el poder económico y político (Areces 2000). En ese proceso de colonización de los territorios tucumanos y de configuración de la sociedad local -especialmente, en lo tocante a las élites- los cabildos asumieron un rol fundamental. La participación en el ayuntamiento otorgaba un mejor acceso al poder político y a la manipulación de los recursos económicos, pero también era de gran importancia el reconocimiento social que revestía el ejercicio de los oficios capitulares. ${ }^{4}$

9 Las dos residencias examinadas pusieron el foco sobre este sector de la sociedad del Tucumán colonial y en ese sentido podría decirse que cada una de ellas constituyó un juicio al poder político local. A ello cabe agregar que sendos juicios, especialmente el de Campero, se inscribieron en un contexto signado por el interés regio de recuperar el control sobre sus dominios indianos e instaurar un nuevo modelo político-social (Brading 1990, Pietschmann 1996). De esa forma, con la progresiva implementación de las reformas borbónicas, especialmente a partir de la segunda mitad del siglo XVIII, la relativa autonomía de las élites locales consolidada a lo largo del siglo XVII se vio amenazada. Al respecto sugerimos que en ese contexto un procedimiento que de por sí responde al interés regio de intervenir y controlar la actuación de los oficiales públicos, habría visto potenciado dicho acervo tanto en la perspectiva metropolitana -orientada a la transformación de la burocracia indiana- como en la perspectiva local -que veía peligrar las prebendas conseguidas hasta entonces.

De cada uno de estos juicios han resultado extensos expedientes que fueron remitidos al Consejo de Indias y que actualmente se encuentran depositados en el Archivo Histórico Nacional, en Madrid; afortunadamente gracias al proceso de escaneo y digitalización los manuscritos también pueden ser consultados online (http://pares.mcu.es/). De esta última manera accedimos y leímos los más de 3500 folios (7083 imágenes escaneadas) que componen la residencia a Tineo, de cuya totalidad transcribimos en esta publicación aproximadamente un 1,5\% (54 folios; poco más de 100 imágenes). En el Archivo el corpus está dividido en dos legajos. El primero incluye 5 piezas y el que le sigue 4 , aunque se trata de una única numeración que comprende de 1 a 9 la totalidad de las mismas. Las primeras 8 piezas contienen los autos obrados en las diferentes ciudades de la gobernación del 
Tucumán en ocasión de este mismo proceso: las piezas número 1 y 2 corresponden al juicio seguido en Salta, la número 3 al de Santiago del Estero, la número 4 al de La Rioja, la número 5 al de Tucumán, la número 6 al de Catamarca, la número 7 al de Jujuy y la número 8 al de Córdoba. La última pieza (9) del expediente contiene el informe final del juez de residencia. Es importante notar que la organización del documento no refleja del todo la cronología que siguió el juicio de residencia. La disposición sucesiva de los 'subjuicios' dentro del expediente no responde al itinerario seguido por el magistrado; al contrario, esos procesos se realizaron simultáneamente en todas las ciudades.

En la Tabla 1, elaborada a partir del proceso a Tineo, se reproducen de manera más desagregada las fases típicas que seguía la residencia.

\begin{tabular}{|c|c|c|}
\hline Etapa & Evento & Contenido \\
\hline \multirow{4}{*}{$\begin{array}{l}\text { Preparativos para } \\
\text { realizar el Juicio de } \\
\text { Residencia }\end{array}$} & $\begin{array}{l}\text { Cédula Real y } \\
\text { provisiones adjuntas }\end{array}$ & $\begin{array}{l}\text { Notifica la realización del juicio de residencia, } \\
\text { designa al juez y explica cómo debe llevarse a } \\
\text { cabo }\end{array}$ \\
\hline & $\begin{array}{l}\text { Presentación de la } \\
\text { Cédula ante el cabildo }\end{array}$ & $\begin{array}{l}\text { Cada cabildo se notifica del proceso, se copia } \\
\text { la cédula y se somete a la comisión del juez } \\
\text { designado }\end{array}$ \\
\hline & $\begin{array}{l}\text { Pregón del inicio del } \\
\text { juicio }\end{array}$ & $\begin{array}{l}\text { El juez respectivo de cada ciudad manda } \\
\text { pregonar oficialmente en la plaza pública el } \\
\text { inicio del juicio con instrumentos musicales }\end{array}$ \\
\hline & $\begin{array}{l}\text { Confección de lista de } \\
\text { residenciados }\end{array}$ & $\begin{array}{l}\text { El juez solicita al escribano de cada cabildo } \\
\text { que le entregue la lista de los sujetos que } \\
\text { ejercieron cargos en el período del } \\
\text { gobernador residenciado }\end{array}$ \\
\hline \multirow{2}{*}{ Pesquisa Secreta } & $\begin{array}{ll}\text { Realización del } \\
\text { interrogatorio }\end{array}$ & $\begin{array}{l}\text { El juez interroga a los testigos. Se les lee un } \\
\text { cuestionario preestablecido para que declaren } \\
\text { sobre la actuación de los funcionarios }\end{array}$ \\
\hline & $\begin{array}{l}\text { Inspección al archivo } \\
\text { del cabildo y visita a la } \\
\text { cárcel }\end{array}$ & $\begin{array}{l}\text { El juez inspecciona documentos de la época en } \\
\text { que los funcionarios han actuado, y visita las } \\
\text { instalaciones de la cárcel }\end{array}$ \\
\hline Pesquisa Pública & $\begin{array}{l}\text { Recepción de querellas } \\
\text { y demandas }\end{array}$ & $\begin{array}{l}\text { Quienes hubieren sido agraviados por alguno } \\
\text { de los residenciados pueden demandarlo ante } \\
\text { el juez de residencia }\end{array}$ \\
\hline \multirow[t]{2}{*}{ Cargos y descargo } & $\begin{array}{l}\text { Elaboración de cargos } \\
\text { contra el residenciado }\end{array}$ & $\begin{array}{l}\text { De la pesquisa secreta y las demandas, se } \\
\text { elabora una lista de cargos contra los } \\
\text { residenciados, la cual se notifica al imputado } \\
\text { que corresponda }\end{array}$ \\
\hline & \begin{tabular}{|l} 
Defensa \\
residenciado
\end{tabular} & El residenciado presenta su defensa \\
\hline
\end{tabular}




\begin{tabular}{|l|l|l|}
\hline \multirow{2}{*}{ Sentencia } & Dictado de sentencia & $\begin{array}{l}\text { El juez de residencia dicta la sentencia. Se } \\
\text { establecen penas y costas }\end{array}$ \\
\cline { 2 - 3 } & $\begin{array}{l}\text { Aprobación del } \\
\text { Consejo de Indias }\end{array}$ & $\begin{array}{l}\text { El juez superior remite todo el expediente al } \\
\text { Consejo de Indias para ser aprobado y } \\
\text { concluye el juicio }\end{array}$ \\
\hline
\end{tabular}

Tabla $N^{\circ}$ 1. Pasos que componen el juicio de residencia. sancionó la Cédula Real para que se efectuara la residencia a Tineo, el terreno donde este proceso tendría su curso iba cobrando forma: con el nombramiento del juez y sus reemplazantes, con las advertencias e instrucciones de cómo debía desarrollarse la residencia, con las consultas del magistrado, etc. Diez años pasaron hasta que el 28 de noviembre el cabildo de Salta asentó la recepción y la notificación del nombramiento de Balthazar Azebey como juez superior de residencia, habiéndose presentado previamente ante el entonces gobernador, don Joaquín Espinosa. El magistrado se estableció y se encargó de seguir la residencia en Salta, ciudad-cabecera de la gobernación donde residían los gobernadores. Para el resto de las ciudades nombró jueces subdelegados, cada uno de los cuales sería recibido en el oficio ante el respectivo cabildo y debía encargarse de indagar la conducta de Tineo y de los funcionarios concejiles en la jurisdicción que se le había comisionado. La residencia duró aproximadamente dos meses y se celebró de manera casi paralela en todas las ciudades. Concluidos lo que podríamos llamar estos subjuicios, los jueces subdelegados remitieron la información a Azebey. Este aunó esos diferentes conjuntos de autos y los dispuso en piezas numeradas, configurando un sólo expediente que envió al Consejo de Indias y que hoy llega hasta nuestras manos (o computadoras).

uando indagamos en el conjunto de autos seguidos en cada ciudad vemos que la documentación está organizada prácticamente de la misma manera. A medida que uno avanza en el examen del expediente al iniciar la lectura de cada nuevo 'sub-juicio' este se aparece como reflejo del anterior. En los autos obrados por los magistrados en cada ciudad se vuelven a reproducir la cédula real que ordenaba la sustanciación de la residencia con el nombramiento del juez, el edicto de residencia y la certificación de su publicación por medio del pregón - lo que daba inicio al juicio-, el listado de los funcionarios residenciados (respectivos a cada ciudad), los mismos bloques de preguntas que fueron consultadas en todas las ciudades, la testificación de los declarantes, los informes sobre las requisas de la cárcel y los archivos del cabildo, copias de documentos elaborados durante el período de Tineo (puestos allí como evidencia)...y gran cantidad de fórmulas, gestos y símbolos que aparecen ordenados en situaciones similares en cada uno de los cuadernos. Las residencias constituyen expedientes que revisten un alto grado de formalización y de sistematización de los datos elaborados en ese contexto. Los extractos que transcribimos del corpus documental surgido a partir de la residencia a Tineo pueden encontrarse reproducidos en cualquiera de las piezas correspondientes a las diferentes ciudades tucumanas en donde se llevó a cabo este mismo juicio. Las pautas son siempre las mismas.

14 La selección de extractos de la fuente que presentamos en parte responde al interés de mostrar y ejemplificar en qué consistían algunos aspectos tradicionales de la residencia, 
como el recibimiento del juez, el edicto de residencia, la publicación del pregón, los cuestionarios consultados a los testigos y las declaraciones resultantes. Cabe aclarar que, a excepción de los testimonios (de los cuales reproducimos ejemplos de distintas ciudades), optamos por transcribir los autos obrados en Salta porque esa versión del edicto y los cuestionarios fue la remitida al resto de las jurisdicciones. En segundo lugar, nos interesa dar cuenta del carácter formalizado de este evento y vinculado a ello las recurrentes fórmulas en que quedaba signada la omnipresencia del rey, puesto que constituyeron elementos clave para formular la pregunta sobre si la residencia podía ser concebida y analizada como un ritual que tenía implicaciones en la construcción y ejercicio del poder. Por último, algunos tramos de esta selección serán retomados para reflexionar sobre las preguntas y perspectivas que surgen desde dicho enfoque.

\section{La residencia como ritual: ¿por qué? Y ¿para qué?}

15 En general, el juicio de residencia ha sido abordado como un mecanismo de tipo jurídico y administrativo destinado al control de la burocracia indiana, lo que efectivamente se condice con el origen, el programa político y la legislación que modeló esta institución. Sin embargo, a nuestro entender, la eficacia de las residencias no debería buscarse tanto en su adecuación a los objetivos de control e intervención que podían ejercer los oficiales reales sobre el gobierno en Indias, donde los resultados parecieran haber sido más bien negativos. Desde nuestra perspectiva la relevancia política que revestía la celebración periódica de las residencias en el contexto de la gobernación del Tucumán residía en que esta institución configuraba una forma de ejercer el poder regio en estos dominios coloniales y aportar a la construcción y reproducción del orden colonial, especialmente a través de hacer presente la figura del rey y reforzar su autoridad por medios simbólicos implicados en la pautas tradicionales del juicio (Smietniansky 2007, 2009). En este sentido, por un lado, nos apartamos de aquellos enfoques preocupados por establecer la eficacia de las residencias en controlar y mejorar la administración de gobierno; mientras que por otro lado, retomamos los trabajos de Tamar Herzog (2000) y de Armando Guevara Gil y Frank Salomon (1994) por cuanto nos muestran los posibles horizontes de estudio sobre el valor simbólico de las residencias y las visitas como instancias productoras del orden que pretendían observar.

Al organizar los trabajos que han estudiado las visitas, residencias y pesquisas, en tanto instituciones que actuaban como mecanismos de control que la metrópoli empleaba en América, Herzog ha distinguido tres perspectivas. En primer lugar, una serie de trabajos se caracterizan por desarrollar una perspectiva jurídica-tipológica, orientada a estudiar la legislación y la práctica procesal que regía y definía a estas instituciones. ${ }^{5}$ Una segunda línea de estudios aborda los expedientes elaborados en el marco de las residencias, pesquisas y visitas como acervos de información sobre otras instituciones coloniales, de manera que su examen permitiría superar una mirada positivista -centrada en la legislación regia como vía para reconstruir el funcionamiento de las instituciones indianas- y acceder al "derecho vivo". Según Herzog, el problema de estos trabajos es que extraen los testimonios contenidos en las fuentes sin considerar el hecho de que tales procedimientos indagatorios hacían a la construcción de un determinado discurso, y que por tanto la información elaborada en esos marcos institucionales no era neutral. ${ }^{6}$ Estas dos clases de abordajes sobre las residencias, visitas y pesquisas concluyen que más allá de las falencias, estos mecanismos de control seguían siendo útiles como una vía para 
obtener información sobre la administración política, identificar sus problemas y formulas medidas en vistas de corregirlos. Por último, una tercera perspectiva se centró en el análisis de los contextos y escenarios sociales en cuyo marco estos procedimientos se llevaban a cabo, atendiendo al hecho de que en la práctica motorizaban o se convertían ellas mismas en instancias de conflictividad social. ${ }^{7}$

Por su parte, a partir del contexto quiteño (1650-1750), Herzog propone otra mirada en el estudio de estas instituciones. Indaga en la dimensión simbólica y la eficacia política del juicio de residencia y entiende a esta institución como integrante de un sistema más amplio que incluye las visitas y pesquisas, a través del cual se desplegaba la comunicación entre Madrid y sus colonias. Sin embargo, destaca que los informes producto de las residencias que eran remitidos a la metrópoli resultaban insuficientes para elaborar un diagnóstico sobre las situaciones y especificidades del contexto americano e intervenir efectivamente sobre las mismas. La relevancia y las implicaciones de las celebraciones que desplegaban las residencias parecerían entonces haber resultado más significativas en el plano local. Contextuadas en una arena de negociación y búsqueda del compromiso social, Herzog aborda las residencias como "ritos de purificación", señalando que estas "eran momentos en los que la presencia del rey se hacía más tangible que nunca y su mano parecía estar por todas partes y respaldando a todo oficial" (2000: 24). Los enfrentamientos que daban soslayados frente al compromiso social y la presencia regia; de esa manera las residencias quiteñas se constituían en una forma de representar y de ejercer el poder. El enfoque de Herzog abreva de los aportes de Guevara Gil y Salomon (2010 [1994]) en el estudio de las visitas a los pueblos de indios. Estos autores sostienen que las visitas eran más que solo el ejercicio de descubrir e indagar en el mundo colonial. Esta forma jurídica de averiguación entendida en términos de un ritual político constituía un acto performativo en cuya secuencia de fórmulas, acciones y palabras se construía el orden social, instalando e inculcando ciertos valores, normas y jerarquías que las sociedades nativas debían acatar como súbditos de la monarquía española. Es decir, la visita coadyuvaba a la construcción del mundo colonial que supuestamente era sólo el objeto de observación del visitador.

18 Nuestra perspectiva de análisis recupera también la propuesta de Guevara Gil y Salomon; y llega en parte a conclusiones similares a las de Herzog para el caso de las residencias pero desde otra perspectiva teórica y formación disciplinar. Si bien, como ya referimos, destacamos la capacidad de la residencia en cuanto ritual para ejercer el poder y construir el orden colonial, no desestimamos su valor como instancia de conflictividad social, lo que implica en alguna medida recuperar la tercera clase de abordaje que distingue Herzog (Smietniansky 2010c). En el proceso de elaboración de nuestro marco conceptual los aportes de Edmund Leach (1976 [1954]), Stanley Tambiah (1985), Victor Turner y Mariza Peirano $(2001,2003)$-y en términos más generales, la etnografía histórica de Geertz sobre el Estado-teatro balinés del siglo XIX (2000 [1981]) - han resultado centrales. En otros artículos nos hemos ocupado en desarrollar y articular algunas de las ideas que recuperamos de sus trabajos. ${ }^{8}$ En esta ocasión optamos por sistematizar las directrices que definen nuestro andamiaje teórico, con vistas a señalar luego las posibles vetas de estudio implicadas en una aproximación etnográfica a las residencias como rituales:

19 1- Ritual como concepto teórico. Usamos el término ritual como una herramienta teórica que nos ayuda a focalizar sobre una porción de la realidad social y nos provee una determinada perspectiva para analizarlo. Por un lado, esto implica que no nos 
preguntamos respecto de si algo es o no es un ritual; en todo caso reflexionamos si un determinado fenómeno puede o no ser analizado a partir del concepto de ritual. Por otro lado, esto supone que la distinción que marcamos entre ritual y no ritual o entre dimensión ritual y dimensión técnica parte de nuestra perspectiva analítica, la que en todo caso debe ser puesta en tensión con la perspectiva de los actores. Aquello que yo 'veo' y distingo como ritual para los actores no necesariamente está diferenciado del resto de las prácticas sociales.

2- Ritual como un tipo de evento extraordinario. El ritual comprende la clase de acontecimientos extraordinarios vistos así desde la perspectiva de los propios actores. Por un lado, perturba los ritmos cotidianos y configura un tiempo y un espacio diferentes, aunque por otro lado, esa instancia extraordinaria potencia o magnifica elementos que ya son comunes en el plano cotidiano de esa sociedad.

21 3- Formalidad y sentido. Se trata de un tipo de práctica con un alto grado de formalización donde la dimensión ritual asume prioridad por sobre las otras. La forma constituye parte del contenido, en tanto el carácter tradicional y rígido de la forma aporta a que los valores transmitidos en el ritual resulten ante la mirada de los individuos como elementos tradicionales, inmutables e incuestionables.

4- Continuum ritual/ no ritual. Considerando las características 2 y 3, podemos decir que todas las prácticas se despliegan en un continuum en que juegan al menos los siguientes ejes: extraordinario/ cotidiano, formalización/ flexibilidad y dimensión ritual/ dimensión técnica.

5- Dimensión ritual. Nos apropiamos de este concepto para usarlo en dos niveles. Por un lado, la dimensión ritual comprende un aspecto simbólico o comunicativo de la acción social. En este nivel más operativo nos orienta a preguntarnos y focalizar sobre los mensajes o los sentidos que son transmitidos a través de una determinada práctica y que van más allá de la finalidad técnica de la misma. Por otro lado, usamos este concepto para hacer referencia a la dimensión de análisis de una determinada problemática (en nuestro caso, el ejercicio del poder en Indias). (El primer nivel recupera los aportes de Leach y el segundo surge partir de la reflexión sobre el análisis de Geertz en Negara.)

6- Carácter performativo de los rituales y de la dimensión ritual de las prácticas. Los conceptos de "ritual" y "dimensión ritual" no solo designan instancias de comunicación; sino que también se las concibe como productoras de la realidad en que operan (en ese sentido, por ejemplo entendemos que los rituales constituyen formas en que se ejerce y construye el poder).

7- Orden y conflicto social. Los rituales pueden ser tanto instancias de reafirmación de la autoridad y el orden social como espacios de conflicto. En un mismo acontecimiento pueden confluir ambas situaciones.

8- Rigidez y agencia. Si bien los comportamientos altamente formalizados dejan poco margen a la acción individual, los rituales también son modelados por los intereses y motivaciones de los participantes.

9- Ritual e historia. Por un lado, si bien por su mismo carácter tradicional los rituales suelen ser contrarios al cambio, como todo hecho social están condicionados por la historia y los contextos locales. Por otro lado, esa historia y esos contextos particulares son modelados y procesados dentro de las mismas formas estables que ofrece el ritual. ritual es un concepto teórico y con las siguientes proposiciones buscamos 'llenar' de 
contenido ese concepto. Desde estos postulados y generalidades que engloba el concepto de ritual partimos para analizar una serie de hechos particulares en una sociedad y en un contexto histórico singular. Pero no buscamos reafirmar estos presupuestos, sino que apelamos a esta noción de ritual como una herramienta a través de la cual mirar y analizar un fragmento de un mundo social específico y pensar conjuntamente toda una serie de aspectos. Los hechos que analizamos tienen la potencialidad de ser todo esto, pero eso lo sabremos solo una vez que nos hayamos aproximados a ellos.

Estos diferentes postulados encierran preguntas y debates teóricos que han sido abordados en el transcurso de la investigación y que se inscriben en el campo de las teorías antropológicas sobre el ritual. Lejos de tratarse de un marco teórico cerrado o dispuesto antes de iniciar la exploración empírica, el mismo se ha construido a partir del diálogo con las fuentes y con los diferentes campos de producción académica con que dialoga nuestra investigación; y en tanto ese proceso sigue en curso, los postulados se ven constantemente en riesgo de ser movilizados y problematizados. Es importante mencionar que su elaboración demandó un gran trabajo de apropiación y discusión teórica, considerando especialmente que las teorías a las que apelamos se han confeccionado en contextos del clásico trabajo de campo etnográfico y entre sociedades diferentes del mundo colonial que nos ocupa, como los kachin de Birmania o los ndembu de Zambia.

Esa reapropiación teórica y la formulación de nuestro propio andamiaje conceptual se fueron desarrollando en diálogo con el examen de las fuentes -que retratamos en el apartado anterior-, con la historiografía dedicada al estudio de la instituciones -cuyas descripciones centradas en los aspectos más formales revisten gran valor para una aproximación etnográfica que hace foco justa- mente en ese acervo formal y tradicional de las prácticas- y también con un reciente terreno de la historia colonial que aborda la significación y las implicaciones de los rituales en la construcción del orden colonial y en el ejercicio y legitimación del poder. Bajo este último enfoque las controversias por cuestiones de "ceremonial" o "cortesía" no se conceptualizan como simple expresión o reflejo de otra clase de conflictos por el poder, sino que se entiende que constituían en sí mismas las maneras en las cuales el poder se construía y se disputaba. En ese mismo sentido, se observa la necesidad de trascender aquellos análisis que buscan explicar las fastuosas y onerosas fiestas coloniales a partir de algún tipo de irracionalidad económica o que reducen el significado de estos festejos a la mera diversión (Ortemberg 2006). Lejos de convocar a tales explicaciones, los trabajos de Cañeque (2004) y de Curcio-Nagi (2004) para México, de Ortemberg $(2000,2006)$ para Lima y un comparativo con Potosí y Cuzco, de Torres Arancivia (2006) y Osorio (2008) para Lima y de Bridikhina (2007) para la Audiencia de La Plata como corte provincial, en su conjunto nos permiten adentrarnos en el desarrollo y las implicaciones políticas del ritual. Los múltiples festejos, agasajos y conmemoraciones de distinta clase -recibimiento y toma de posesión de los virreyes, exequias y juras reales, fiestas religiosas, solo por mencionar algunos ejemplos- que coloreaban la vida de la sociedad americana y el alto grado de formalización que caracterizaba las interacciones cotidianas y los vínculos que mantenían entre sí las autoridades del mundo colonial, no son concebidos como epifenómeno de la estructura social sino que, precisamente, se aborda su capacidad para construir el orden colonial, para asignar lugares y otorgar prestigio, para desautorizar o legitimar posiciones de poder. Estos trabajos nos permiten aproximarnos a algunas de las características que asumía el ejercicio y la concepción del poder; entre ellas, la importancia que revestía la 
expresión y la visibilidad de 'poseer' ese poder para hacer legítimo y efectivo su ejercicio. Asimismo, esta centralidad del ritual como instancia que expone la posesión de ese poder debe también entenderse en el marco de un sistema político que debía dar respuesta a la ausencia física del rey, quien constituía la fuente de poder y de legislación. El ritual y los símbolos -retratos, sellos y pendón reales, la figura del virrey como alter-ego del rey, etc. - actuaban construyendo la presencia del monarca en estos dominios territoriales. A lo largo de nuestra investigación dichos trabajos han constituido un fértil terreno para reflexionar sobre el vínculo entre ritual y poder en el contexto del mundo social y del marco institucional que abordamos.

31 Vistas entonces las implicaciones del ritual en ese contexto, la aproximación que proponemos al estudio de las residencias en la gobernación del Tucumán nos conduce a repensar el análisis de esa clase de instituciones y por tanto el examen de los expedientes resultantes.

\section{Las residencias en perspectiva ritual}

32 El uso que hacemos del concepto de "ritual" nos lleva a focalizar y problematizar sobre determinados aspectos de los hechos que hemos de describir y analizar. Los siguientes ítems recuperan algunas de las dimensiones propuestas en el estudio de los rituales con vistas a explorar los modos en que puede ser interrogado y analizado el expediente resultante en el caso de Tineo. De esta manera, buscamos llevar esa suerte de complejo de coordenadas teórico-metodológicas que desglosamos en el apartado anterior al estudio de las residencias, reflexionando sobre qué aspectos ilumina y qué nuevas preguntas o problemas pueden ser formulados a partir de dicho enfoque. ${ }^{9}$

1- La residencia instruida a Tineo y a todos aquellos que ocuparon cargos en los cabildos del Tucumán durante su mandato insumió unos dos meses, dejó tras de sí un expediente de más de 7000 fojas y las costas contabilizaron un total de 10720 pesos. Tineo resultó libre de todo cargo y suerte similar corrieron el resto de los funcionarios residenciados en las diferentes ciudades. Más allá de algunas pocas inculpaciones resultantes, Azebey concluyó prácticamente librando a todos los imputados de los cargos que habían levantado los respectivos jueces subdelegados en cada ciudad y a lo sumo, imponiendo unas leves penas monetarias. Si evaluamos este panorama en términos de los objetivos estipulados en la legislación concluiríamos que la residencia resultó ineficaz. Ahora bien, si la repensamos en términos de un ritual es posible formular otras preguntas desde donde interrogar la misma fuente: ¿En qué reside el sentido de impulsar una empresa de esa envergadura - destinando gran cantidad de esfuerzo, tiempo, dinero y gente- para unos resultados que serán mínimos? ¿Es posible entrever otros sentidos que van más allá de su dimensión jurídica de control? Al conceptualizarla como un ritual, la noción de eficacia se traslada del plano jurídico al plano simbólico. Vista como un ritual e interrogada su eficacia simbólica -su carácter performativo-, encontramos que la residencia aportaba a la recreación de un orden ideal de las instituciones y potenciaba la figura del rey sobre estos dominios (Smietniansky 2007).

2- Para llegar a esa interpretación fue necesario atender a la extrema formalidad y al carácter de evento extraordinario que asumía la residencia. Señalamos que los rituales configuran un tiempo y espacio diferentes al cotidiano, y que esa redefinición está justamente signada por el carácter extraordinario del ritual, aunque allí se potencian o magnifican elementos propios del orden cotidiano. Ahora bien, ¿podemos interrogar el 
expediente de la residencia a Tineo considerando esta dimensión? ¿Qué aspectos ilumina o qué ventajas conlleva abocarnos a su análisis? Sabemos que el tiempo de la residencia revestía un carácter efímero: duraba 60 días, pasados los cuales caducaba la comisión del juez y se disolvía el juzgado de residencia. Como ya referimos antes, la residencia se realizó de manera paralela en todas las ciudades; en cierta medida equiparó sus tiempos, siendo que cada una de ellas se constituyó en escenario de una misma serie de actividades (notificación y recibimiento de los jueces, elaboración de la lista de residenciados, interrogatorios, cargos que levantaba el juez, defensa, sentencia, etc.). Como surge de la fuente transcripta, Azebey dejaba en claro que la publicación del pregón debía realizarse el mismo día -22 de enero de 1764-en todas las ciudades. Esta suerte de sincronización probablemente haya repercutido perturbando las rutinas o tiempos ordinarios. Aunque otros elementos nos llevan a pensar que también se superpuso -y no solo perturbó- a los tiempos locales. En el partido de Ischillín (Córdoba) quedó testimoniado que la publicación del pregón se realizó "en concurso y hora de la misa mayor..." , ${ }^{10}$ de manera que esta empresa extraordinaria se sirvió del contexto de un ritual religioso preestablecido y de la convocatoria que este presuponía. A ello cabría agregar que la residencia a Tineo (igual que en el caso de Campero) tuvo lugar en un tiempo de por sí ritual: hacia fines de 1763 y comienzo de 1764. Fecha crucial del calendario religioso y también del calendario político (con las elecciones capitulares).

En relación con la construcción del espacio, advertimos que la residencia definía una territorialidad de escala regional que trascendía el ámbito local de las respectivas ciudades al reafirmar la extensión y límites de la jurisdicción del Tucumán bajo dominio del rey. Esto puede verse en la misma distribución de la cédula real y en la publicación de los pregones que se usaban para notificar a todo el conjunto social sobre el inicio y la forma del proceso. El 'epicentro' del juicio era Salta y desde allí Azebey remitió las mismas instrucciones a los jueces subdelegados asentados en el resto de las ciudades; el espacio allí se 'abrió' para volver a replegarse dos meses después, cuando esos mismos magistrados le enviaron a Salta los autos obrados en cada ciudad. Con respecto al inicio y notificación de la residencia, al tiempo que cada juez subdelegado se encargó de seguir la publicación del pregón en la plaza pública de la ciudad que le había sido comisionada, mandó se publicase el mismo día en "parajes acostumbrados", los pueblos y las capillas de cada jurisdicción. Por ejemplo, en La Rioja el juez subdelegado, Joseph Ambrosio Cansinos, remitió copias del edicto a 4 partidos - Arauco, Los Llanos, Anguinan y Guandacol-y ordenó que su contenido se pregonara también en esa fecha; él se encargó de publicarlo en la ciudad. De esta manera la residencia utilizó y resignificó lugares propios del orden ritual local.

Sugerimos que el tiempo de la residencia se hacía uno en la medida en que los múltiples lugares que constituían la gobernación del Tucumán eran escenario de la misma actividad, y en ese proceso ese espacio regional también se constituía en unidad. La residencia señalaba los límites de la jurisdicción del Tucumán y, con ello, la pertenencia de todos sus habitantes como parte de una misma comunidad que abarcaba el plano local de las ciudades; y sobre la cual estaba interviniendo el poder regio.

Estas observaciones - surgidas de abordar la residencia como ritual, en su dimensión tempo-espacial- nos dan la pauta para pensar otro problema vinculado con la representación de la pertenencia social o la construcción de las identidades. Advertimos que esta celebración no solo integraba o cohesionaba a los miembros de las sociedades locales, sino que justamente a través de su convocatoria (regida por el imperativo de 
notificar a todos los habitantes) se establecía la diferencia entre el ser reconocido como parte de la comunidad o no. ¿Puede esta observación servir como puntapié para reflexionar sobre las implicaciones de esta clase de procedimientos en la configuración de las identidades regionales? O dicho de otra forma, ¿sobre los modos en que los protagonistas de este mundo social se representaban su pertenencia a diferentes agregados sociales? Al mismo tiempo, cabría también indagar en qué medida el diferente grado de participación que los individuos asumieron en la residencia podía resultar indicativo de la pertenencia social. A la población indígena sólo la vemos aparecer en la instancia de la publicación del pregón y no con la misma relevancia en todas las ciudades; mientras que fueron los miembros de las élites locales quienes actuaron como magistrados, testigos e imputados durante todo el proceso.

3-La extrema formalidad del ritual no impidió que los actores -individuos y faccionesse apropiasen de él y, dentro de los márgenes de acción impuestos por la residencia, se condujeran en función de sus intereses y de sus disputas preexistentes. En general, los testimonios fueron más bien tendientes a ocultar las rencillas y disputas locales, apelando a las clásicas fórmulas "no sabe", "no tiene presente" y "no recuerda", entre otras. Esos relatos aportaban a la construcción de una imagen casi ideal de la administración pública local. En algunos pocos casos, los declarantes dejaron en evidencia el carácter endeble del autorretrato de gobierno. En ese sentido los testimonios transcriptos, a modo de ejemplo, sirven para dar cuenta del tipo de respuestas y tácticas susceptibles de ser desplegadas, que iban desde el ocultamiento total del conflicto y la reafirmación del orden social, hasta la expresión sin tapujos de los problemas y disputas. A nuestro entender el reconocimiento de las apropiaciones realizadas por parte de los participantes de la residencia señala la necesidad de problematizar de qué manera esto se conjugaba con la capacidad de este ritual para aportar a la reafirmación del orden social.

4-Esta celebración concentraba en tiempo y espacio un simbolismo de poder que en el caso del funcionamiento del cabildo decantaba en sus consecutivas sesiones a lo largo del ciclo anual. En esos dos meses la marcada presencia de la figura del rey pareciera haber revertido hasta 'saturar' el expediente: la cédula real se esparció por toda la gobernación en poco tiempo y su recepción conllevaba el clásico 'ritual' de acatamiento -disponerla sobre la cabeza y besarla-, él era el objeto por el cual juraban los testigos, imputados y magistrados, en su nombre de daba comienzo al juicio y se dictaba sentencia, los jueces actuaban en representación suya, etc. Imaginemos estos procedimientos reproducidos una y otra vez en cada ciudad. La residencia constituía algo así como una versión aumentada, magnificada, de los múltiples dispositivos de poder que hacían a la vida ordinaria del cabildo y de sus funcionarios. En ese sentido, se acerca a uno de los modos en que Mariza Peirano caracteriza a los rituales y entrevé la potencialidad que encierra su análisis: se trata de "um fenómeno especial da sociedade, que nos aponta e revela representacões e valores de uma sociedade, mas o ritual expande, ilumina e ressalta o que já é comum a um determinado grupo" (2003:10). Esta idea nos conduce a pensar dos enfoques en el abordaje de la residencia como ritual: un primer enfoque nos dispone a atender a la significaciones y las implicaciones que revestía como instancia de construcción y ejercicio del poder; y una segunda perspectiva advierte que la residencia en cuanto ritual también puede ser concebida como una vía para aproximarnos al estudio de la sociedad y el orden político en que tenía lugar.

5- Al detenernos sobre las relaciones entre historia y ritual en el marco de la residencia advertimos que el problema puede abordarse en dos direcciones. Por un lado, indagando 
de qué manera los procesos históricos operaron modelando y otorgando características singulares a cada residencia, o dentro de cada residencia a cada sub- juicio local. Por otro lado, también pueden explorarse los modos en que los hechos del pasado eran insertos y resignificados en la celebración de las residencias y en los expedientes que a lo largo de cada performance se iban elaborando.

Los múltiples relatos que quedaron registrados en los expedientes de las residencias testimonios de los testigos, autos de requisas del propio de juez, descargos de los residenciados, transcripción de documentos elaborados en el mandato del gobernador que estaba siendo residenciado, etc. - fueron construidos desde determinados marcos de significación. La residencia imponía una delimitación temporal y un recorte temático. Este último estaba dado por el cuestionario (véase la transcripción) con que se interrogaba a los testigos, que entonces operaba seleccionando qué tramos de las historias, los sucesos y los problemas locales en que estaban involucrados una serie de exfuncionarios capitulares podían ser objeto de los relatos por parte de los declarantes. En cuanto a la delimitación temporal, la residencia a Tineo indagó sobre lo acontecido durante el período de ese gobernador; el juez no tenía competencia para imputar delitos cometidos por fuera de ese período. Para hacer referencia a ese tramo de tiempo los declarantes, imputados y magistrados lo hicieron en términos de "el tiempo de la residencia", "en el tiempo de esta residencia", "en el tiempo de Tineo", "el tiempo de dicho gobernador", entre otras categorías. Es decir, la residencia de carácter transitorio (duraba 60 días) y situada en el orden del 'presente' se encargaba de evaluar lo acontecido durante un período de tiempo pasado cuyo comienzo y fin no estaba dado 'objetivamente' o de antemano por lapsos anuales, sino que se veía marcado por la extensión del mandato del gobernador Tineo.

42 Estas observaciones plantean interrogantes sobre la construcción de la historia que ha quedado asentada en esos expedientes. Podríamos pensar que la residencia en alguna medida compelía o impulsaba la reconstrucción de una historia y, en particular, marcaba el comienzo y el final de unas experiencias pasadas que no necesariamente tuvieron que haber sido enmarcadas por los actores bajo ese período de tiempo. De hecho, la residencia en este caso aunaba las historias locales al definir una cronología situada en la escala regional -la gobernación, el mandato de Tineo- y no en términos de los calendarios locales -como, por ejemplo, podría haber sido el mandato anual de los alcaldes ordinarios-. En este punto puede resultar interesante avanzar en una comparación con la temporalidad y la cronología que caracterizaba a los archivos de los cabildos.

43 Ahora bien, ese ejercicio de construcción del pasado no es lineal: por un lado, este ritual regio implicaba el ejercicio de clasificar y ordenar el mundo político y social que era objeto de indagación, aunque, por otro lado, en ese proceso de 'tabulación' las coyunturas históricas particulares y los contextos locales confirieron a cada celebración un carácter único. Aquí reside la segunda dirección en que pensar la relación ritual e historia.

En cuanto a la elaboración de los cuestionarios, Azebey llegó a la gobernación del Tucumán portando, además de la cédula real y una provisión auxiliatoria de la Audiencia de Charcas, un despacho del virrey - Conde Superunda - confirmando su comisión para efectuar la residencia de Tineo. Dicho auto incluía un extenso cuestionario para tomar declaración a los testigos sobre la labor del gobernador. Sin embargo, Azebey encontró cierto desfasaje entre dicho interrogatorio y la situación del Tucumán. El cuestionario enviado por el virrey para indagar sobre la conducta del gobernador estaba enfocado sobre la figura del corregidor y, fechado en 1761, se contextuaba en un clima de revueltas 
y levantamientos motivados por la profundización de las tensiones que supuso la legalización de los repartimientos (1751) entre las comunidades indígena y los grupos de poder coloniales (el corregidor, los curas locales, los caciques y los administradores de obrajes y haciendas) (O’Phelan Godoy 1988). Dicho cuestionario traía consigo preocupaciones sobre el efectivo y adecuado funcionamiento de dicha institución, las condiciones de trabajo de la población indígena y el acrecentado poder de los encomenderos (que interesaba controlar), entre otros temas. Esta perspectiva inquisitiva resultaba por tanto bastante alejada de la realidad en que indagaba Azebey, donde no había repartimientos ni tampoco operaba la figura del corregidor. En ese sentido, luego de dejar asentado en el expediente y certificado por escribano la inexistencia de cajas de comunidad en la provincia -sobre lo cual indagaba el cuestionario remitido por el virrey (véase transcripción)-, procuró ajustar las preguntas al panorama de la gobernación tucumana, incluyendo un nuevo conjunto de preguntas (que solo aparecen en el caso salteño), y otorgó a los jueces subdelegados esta misma facultad para acrecentar el interrogatorio con nuevas preguntas. Esto demuestra los márgenes que proveía el propio juicio para amoldarse a las situaciones o coyunturas locales.

Ahora bien, la comparación sobre las formas que adoptó el mismo juicio en diversas ciudades, y la comparación entre dos residencias acontecidas en períodos cercanos pero diferentes, también aporta para abordar el modo en que las coyunturas locales e históricas se filtraban y resultaban expuestas en ese marco ritual, y cómo actuaban modelando o condicionando su celebración.

Por ejemplo, el eje del conflicto al que debieron responder Tineo y Campero en sus respectivos mandatos fue diferente -más allá de que en el marco de cada residencia los mismos resultaron más bien silenciados-. Durante el período de Tineo el conflicto estaba puesto en la frontera chaqueña y en la guerra contra el indio, y en todo caso el mismo revirtió en el plano interno por la resistencia de algunas ciudades a participar de las campañas al Chaco (Vitar 1997). En la gobernación de Campero el foco del conflicto fue de por sí motorizado en el terreno interno y se vinculaba con la implementación de las reformas borbónicas a cargo de este "típico funcionario borbónico" (Lorandi 2008), las cuales venían a socavar el poder de las élites coloniales fuertemente imbricadas con la orden jesuítica. Incluso podemos pensar los cuestionarios a partir de estos contextos. Al comparar las preguntas consultadas a los testigos en una y otra residencia, advertimos que la residencia a Campero focalizó aún más que la de Tineo sobre la dinámica faccional de los cabildos, lo que puede vincularse con un contexto caracterizado por el avance de las reformas borbónicas y el interés del poder regio en intervenir y transformar las instituciones corporativas tradicionales.

6- De lo dicho hasta ahora y recuperando las ideas de Peirano, vemos que las residencias -en cuanto rituales- pueden pensarse como instancias privilegiadas para abordar la sociedad colonial, puesto que allí confluían y se potenciaban aspectos propios y usuales de dicho contexto. Incluso, por su misma organización en conjunto el expediente se asemeja a una suerte de fotografía de la estructura política regional y local. Sin embargo, la unidad del ritual no debe solapar la presencia de actores diversos que participaban en ese acontecimiento. Al respecto se apunta sugerente la diversa imagen que resulta del gobernador Tineo en las distintas jurisdicciones. Como surge de los extractos transcriptos, el detalle de los testimonios salteños que recuperaban la cercanía y la cotidianeidad que los declarantes compartían con Tineo se hace más visible al compararlo con las exposiciones registradas en Catamarca, Tucumán y La Rioja. La figura del 
gobernador en esos contextos perdía cercanía o resultaba opacada por el protagonismo que cobraban los lugartenientes. La conducta de Tineo y la de sus tenientes eran consultadas bajo un mismo bloque de preguntas. Si por ejemplo tomamos el juicio seguido en Catamarca y Tucumán, la mayor parte de los testigos podía dar precisiones sobre el accionar de Joseph Luis Díaz - teniente de gobernador en ambas ciudades- pero manifestaba desconocimiento sobre los diferentes aspectos de la vida del gobernador. Estos detalles constituyen indicios que nos permiten entrever de qué modo era percibida la figura de Tineo en el contexto de las ciudades más alejadas de la residencia del gobernador en Salta y, en relación a ello, qué sucesos quedaron plasmados en el recorte de la historia local. Volviendo aquí a la cuestión de la historia, cabe notar los conocimientos y experiencias dispares de los testigos cuando relataban la llegada de Tineo a la jurisdicción y la toma de posesión de su cargo.

En conjunto estos elementos nos hacen interrogarnos en qué medida el expediente elaborado en el marco del juicio puede constituirse en un terreno propicio para abordar la construcción de las memorias de cada ciudad, atendiendo a que precisamente la residencia expone recortes heterogéneos sobre el pasado y, en este caso particular, sobre la persona de un gobernador. Por otro lado, esta clase de análisis puede entablar diálogo con otros trabajos que, como los de Osorio (2008) y Herzog (1997), han abordado las distintas formas en que la figura del virrey y del rey fueron construidas y percibidas en las distintas regiones, atendiendo, entre otros, al carácter más o menos lejano de cada uno de ellos y a la mediación simbólica que ofrecían los rituales. En un territorio como el tucumano, alejado de las fastuosas entradas y tomas de posesión virreinales, quizá la figura del gobernador y el proceso de llegada a la jurisdicción para incorporarse en el cargo, atravesando las diferentes ciudades (aunque no todas) - de acuerdo a como lo encontramos registrado en los relatos contenidos en el expediente de Tineo-, pueda constituirse en un punto de comparación y en un terreno para continuar explorando el ejercicio ritual del poder visto a través de los actores locales y de sus perspectivas socialmente situadas.

\section{Reflexiones finales}

Como tratamos de mostrar a lo largo de estas páginas la teoría constituyó un insumo clave para abordar la residencia como un ritual y trasladar ese enfoque al examen de las fuentes documentales. Entendemos que esto no niega la residencia en su dimensión jurídica y en cuanto procedimiento regio de control; lo que hace es iluminar otros aspectos de estas celebraciones, señalando las implicaciones que revestían especialmente en los contextos locales en que tenían lugar. A nuestro entender esto también da cuenta de la vigencia de los autores clásicos en Antropología y de la fertilidad de aproximarnos etnográficamente a los materiales de archivo.

La conceptualización de la residencia como ritual no ha consistido en una mera clasificación de este acontecimiento. Al contrario, fue a través de problematizar ese uso conceptual -ejercicio central para una aproximación que pretende ser etnográfica-y de discutir si efectivamente podía ser así comprendida, de donde fueron surgiendo las diferentes problemáticas que en mayor o menor medida hemos analizado a lo largo de la investigación y en esta ocasión reseñamos. Producto de ese diálogo entre teoría y campo construimos una serie de postulados o directrices teóricas que sirven a los efectos de sistematizar el abordaje en términos del concepto de ritual. Ahora bien, a nuestro 
entender, ese listado constituye sólo el punto de partida para enfocar el análisis de los hechos y elaborar nuevas preguntas. El ejercicio que propusimos de trasladar esas coordenadas teórico-metodológicas al examen de la residencia instruida a Tineo da cuenta de que, junto con el análisis focalizado sobre ciertas dimensiones del ritual, van surgiendo nuevos interrogantes, que no necesariamente pueden o deben ser respondidos 'a partir del ritual'.

51 La posibilidad de transcribir parte de la fuente nos brinda otros recursos para reflexionar y comunicar más vivamente los modos en que la misma ha sido interrogada y examinada. Es decir $-\mathrm{y}$ esto puede verse a través de la lectura del extracto reproducido-, nada hay en los 'datos en bruto' que nos indique que estamos ante un ritual, que a través del mismo se recreaba un espacio jurisdiccional, que en su celebración se vivía un tiempo diferente o que hay allí historias que estaban siendo construidas. Todo esto se sitúa en el plano de las interpretaciones o de los problemas que elaboramos a partir de la lectura y análisis del expediente resultante de dicha residencia. Lo que tratamos de mostrar a lo largo de este artículo son algunas de las mediaciones que operaron en la construcción de esas preguntas e interpretaciones; en particular una de esas mediaciones, que reside en la manera en que la teoría elaborada sobre el ritual informó y condicionó nuestra mirada.

Fuentes

Archivo Histórico Nacional (AHN), Madrid. 1775-1777. Residencia de Juan Manuel Campero, gobernador de Tucumán. Consejos, 20373, expediente 1.

AHN, Madrid. 1753-1792. Residencia de Juan Martínez de Tineo, gobernador de Tucumán. Consejos, 20374, expediente 1. Incluyes piezas 1, 2, 3, 4 y 5.

AHN, Madrid. 1753-1792. Residencia de Juan Martínez de Tineo, gobernador de Tucumán. Consejos, 20375, expediente 1. Incluyes piezas 6, 7, 8 y 9.

Anexo: RESIDENCIA DE JUAN MARTÍNEZ DE TINEO, GOBERNADOR DE TUCUMÁN

Referencia: Archivo Histórico Nacional (Madrid). Consejos 20374, expediente 1 (piezas 1, 2, 3, 4 y 5), y Consejos 20375, expediente 1 (piezas 6, 7, 8 y 9).

Nota 1: La numeración de los folios corresponde a la otorgada por el Archivo Histórico Nacional que al escanear el documento ha dispuesto un nuevo ordenamiento.

Se ha actualizado la escritura y la ortografía del manuscrito original para facilitarle al lector el acercamiento a estas fuentes.

Nota 2: Dado que se transcribe una porción pequeña del extenso expediente, para clarificar su lectura optamos por establecer las secciones A), B) y C), indicando allí la naturaleza de los extractos reproducidos. Cada una de ellas responde a una etapa singular de la realización de la residencia. Asimismo se incluyen algunas aclaraciones entre corchetes.

A- Recepción del juez superior de residencia ante el gobernador y el cabildo de Salta; instrucciones dadas a Tineo al asumir su cargo; edicto de residencia y pregón que marca el comienzo del juicio.

En la ciudad de Salta a veintiuno de noviembre de mil setecientos y sesenta y tres años el señor don Joachín Espinosa y Dávalos Teniente Coronel de Infantería de los Reales Ejércitos Gobernador y Capitán General de esta provincial del Tucumán. Habiendo visto la Real Provisión de las fojas antecedentes, estando en pie, y destocado / folio 65 r/ su señoría la tomó entre sus manos, besó y puso sobre su cabeza como a Carta y Real Provisión de nuestro Rey y señor natural, a quien la divina Majestad guarde y prospere con aumento de mayores reinos, y señoríos como la cristiandad ha de menester y en cuanto a su cumplimiento que se guarde y cumpla como su Alteza lo manda, sin que por las justicias, ni otra persona alguna se le ponga embarazo en su 
comisión al expresado don Balthazar de Azebey y antes bien le den todo el auxilio que hubiere de necesitar, y les pidiese, a que está pronto este gobierno como en el despacho y real cédula lo tiene expuesto hoy día de la fecha, para cuyo efecto se le devuelvan y así lo proveyó y firmó su señoría de que doy fe.

Joachín Espinosa [gobernador]

Ante mí

Francisco López Zevallos

Escribano público y de cabildo

Vista la provisión de las fojas antecedente se /folio 65v/ obedeció por sus mercedes los señores vocales que abajo firman y en su cumplimiento mandaron que no se le pongan impedimento alguno en el uso y ejercicio de Juez Mayor de Residencias al señor Don Balthazar de Azebey por el tiempo que corresponde al gobierno que ejerció en esta provincia el señor Coronel don Juan Victorino Martínez de Tineo antes bien al dicho señor juez de residencia se le den todos los auxilios y el fomento que necesitase como está pronto cada uno de sus mercedes en lo respectivo a su cargo según que más expresamente se mandó en el acuerdo de este día y en él su aceptación y juramento con lo cual y para que se le devuelva al citado señor juez de Residencia lo firmaron sus mercedes de que doy fe en Salta y noviembre veintiocho de mil setecientos sesenta y tres años.

Domingo de Pucheta

Francisco Rodriguez de Sinde

Juan Calixo

JuanAdrián Cornejo

Ruiz Gauna

Ante mí

Francisco López Zevallos Escribano público y de cabildo

$[\ldots]$

[Instrucciones dadas a Tineo al asumir su cargo (Pieza 1, folios 86r-88v). La pregunta número 44 del interrogatorio correspondiente al gobernador y sus tenientes, que se reproduce en la sección B), hace referencia a estas instrucciones y sobre las mismas responden los testigos]

Instrucciones de lo que debe observar en el comando de la Provincia del Tucumán el Teniente Coronel don Juan Victorino Martínez de Tineo, a cuyo gobierno se haya promovido, y de orden del Rey, comunicada por el excelentísimo señor Marqués de Ensenada en carta de 17 de mayo de 1747 se me previene.

$1^{\circ}$ - Primeramente antes de tomar posesión del empleo de Gobernador y Capitán General, deberá dar fianzas legas llanas y abonadas, ante el cabildo de la ciudad de Córdoba, capital de la Provincia, en la cantidad establecida y practicada por sus antecesores; haciendo el juramento ordinario de fidelidad, y observancia de las leyes Reales en la ciudad de Santiago de Chile, tránsito preciso para su destino ante el señor Presidente, Gobernador y Capitán General de aquel Reino, según lo determinado por el Rey.

$2^{\circ}$ - Luego que haya tomado posesión del Gobierno hará cesar en sus respectivos mandos todos los tenientes de la provincia, nominados por sus antecesores, y en caso de hallar por conveniente elegir otros en su lugar /folio 86v/ os nombrará, y de no, elegirá Gobernadores de las Armas en todas las ciudades, procurando sean los más idóneos, y que hayan manifestado su celo, y empeño 
al Real Servicio, con cuya providencia queda la administración de justicia civil criminal y política a cargo de los alcaldes ordinarios.

$3^{\circ}$ - Guardará, y cumplirá todas las Reales ordenanzas cédulas y leyes, y lo dispuesto en ellas para el entero cumplimiento de su conciencia, y cargo, buen tratamiento de los indios, y recta administración de justicia; y deberá conocer en primera y segunda instancia de todas las causas civiles, y criminales que se ofrecieren en toda su jurisdicción, otorgando según derecho las apelaciones que interpusier en parala Real Audiencia de Chuquisaca.

$4^{\circ}$ - Cuando saliere a la visita ordinaria de la jurisdicción o a alguna comisión de este superior gobierno no ha de obligar a los indios a que le den bastimentos ni bagajes sino es que voluntariamente lo hagan, porque les debe pagar justamente lo que importase, según el común precio y estimación. /folio 87r/

$5^{\circ}$ - Siendo uno de los principales encargos del Rey, el conocer y reprimir los indios rebeldes fronterizos deberá aplicar para el libre tráfico de los caminos, seguridad de la Provincia, y de los viandantes, el mayor, y más vigilante desvelo, sin omitir las entradas anuales para hostilizarlos y castigarlos en su mismo país, embarazando por este medio las invasiones de dichos indios.

$6^{\circ}$ - Igual atención, empeño y desvelo corresponde a extinguir el introducido abuso de la internación o tránsito para las Provincias de esta Gobernación y Chile, de géneros prohibidos de ilícito comercio que suele la codicia transportar de la colonia portuguesa del Sacramento para la vía del Buenos Aires, y de él a dicha colonia; y para arrancar de raíz este pernicionismo, y perjudicial abuso, aplicará las más vivas, y activas diligencias, poniendo guardias de la mayor confianza en los caminos, parajes y surtidas que juzgare más precisas, y de recelo para el transporte de dichos géneros, plata y oro sin quintar; celando sobre las mismas guardias por medio de algunas espías /folio $87 \mathrm{v} /$ tenga seguridad y confianza.

$7^{\circ}$ - Como asunto tan conducente a la consecución del capítulo de arriba, expedirá los más estrechos órdenes con la facultad necesaria a todos los tenientes y justicias, y jueces particulares de la provincia, para que comisen todos los géneros que transiten de Buenos Aires a las provincias del Perú, y Chile, sin preciso registro y guía de juez competente, como también la plata y oro sin quintar, que de los referidos parajes condujeren a Buenos Aires ofreciendo a todos los que hagan algún descamino de cualquiera de las especies referidas la parte que les tocare según la distribución dispuesta por Leyes Reales y Cédula de su Majestad.

$8^{\circ}$ - Con el mismo empeño deberá poner le mayor cuidado, y vigilancia, a fin de que no se transiten por caminos extraviados los efectos, sujetos a pagar lo respectivo del Real ramo de sisa, valiéndose para eso de los mismo guardias destinado a embarazar el ilícito comercio; para que con esta providencia no se defraude este ramo, que es el /folio 88r/ único para pagar el diario mensual o anual, al número de tropa establecida de doscientos hombres, que es la vara fundamental en que estriba la seguridad de la frontera, y tranquilidad de los vecinos y naturales de la provincia; haciendo todo empeño se restablezca este ramo a su antigua opulencia.

$9^{\circ}$ - Respecta a haber determinado el Rey formar, y establecer en la ciudad y Puerto de Buenos Aires almacén o estanco de tabaco selectos, para que se provean las provincias del Río de la Plata, Tucumán, y Paraguay, con prohibición absoluta de que sin caer en la pena de comiso se puedan internar otros por el Perú, ni Chile, porque irá remitiendo de España según lo ha ejecutado los respectivos con abundancia a los abastos necesarios; deberá celar, y evitar la internación de otros cualesquiera tabacos, y que los que se condujeren de Buenos Aires a las / folio 88v/ provincias, vayan con certificaciones y guías, de los ministros, o estanqueros deputados a este fin.

Lima 30 de marzo de 1748

Don Joseph Mansos [Virrey de Perú] 
$[\ldots]$

[Edicto de residencia y su publicación (Pieza 1, folios 155r-156v)]

Don Balthazar de Azebey juez privativo de cuentas y residencia de la que debe dar el señor coronel de Infantería don Juan Victorino Martínez de Tineo del tiempo que ejerció del empleo de Gobernador y Capitán General de esta provincia del Tucumán sus lugartenientes generales particulares cabildos justicias y demás oficiales y ministros de su tiempo por especial comisión que para ello tenga de su Majestad que Dios guarde.

Hago saber a todos los vecinos y moradores estantes y habitantes de esta ciudad de Salta y de las demás de esta dicha Provincia y Gobernación sus términos y jurisdicción de cualquiera estado calidad y condición que se any a los caciques curacas e indios naturales de sus distritos como el Rey Nuestro Señor que Dios guarde me tiene ordenado y mandado por su real cédula dieciséis de noviembre del año pasado de mil setecientos cincuenta y tres que se halla obedecida y mandada observar por la real Audiencia de la ciudad de La Plata según consta de real Provisión librada en ella su fecha en ocho de julio de este presente año para que se tome la residencia al Coronel de Infantería don Juan Victorino Martínez de Tineo Gobernador y Capitán General que fue de esta dicha provincia sus tenientes cabildos justicias y de /folio 155v/ más ministros como son alguaciles mayores sus tenientes procuradores mayordomos receptores de penas de cámara y gastos de justicia defensores de menores y de bienes de difuntos protectores de indios jueces de aguas y de comisión alcaides y otros cualesquiera personas que según derecho y costumbre deban dar residencia del ejercicio y uso de sus oficios del tiempo de dicho gobierno por tanto si alguna persona o personas se hallasen y estuviesen perjudicadas o agraviadas de las comprendidas o de sus ministros y escribanos que se contienen en las memorias sacadas de los que son residenciados que se ha de leer cada una con su edicto o de ellas hubiere recibido y padecido injuria injusticia y malos tratos en personas, honras o haciendas servicios personales deudas o jornales que le tengan quitadas o porque no hayan obedecido reales provisiones y despachos superiores por omisión o negligencia en la administración de justicia o por mal juzgado o por demasiados derechos que les hayan llevado pública o secretamente o por otra cualquier razón o derecho que tengan que pedir o demandar civil o criminalmente de todos y cualesquiera de dichos residenciados comparezcan en este mi juzgado dentro del término de sesenta días que han de correr y contarse desde el día de la publicación de este edicto de residencia que es el término en que se ha de tomar y concluir en conformidad de lo mandado lo cual hagan libremente y sin recelo ni temor alguno de que por ello serán molestados ni agraviados porque desde luego en virtud de la jurisdicción que obtengo bajo del real amparo para que por ninguno de dicho residenciados ni de otra persona se les impida ni atemorice a que dejen de / folio 156r/ pedir justicia y demandarla y si lo dejaren de hacer por el mismo hecho las tales personas que impidieren y estorbaren han de incurrir en las penas declaradas por derecho contra los que quebrantaren el seguro real con más con la de quinientos pesos ensayados aplicados por mitad para la real cámara de su majestad y parte damnificadas y se les asegura que si en el dicho término expresado padecieren y pidieren justicia serán oídos y se les guardará en vía de residencia y pasados no serán oídos ni admitidos los dichos demandantes y a los dichos residencia dos desde luego por este edicto los cito llamo y emplazo para que asistan y den dicha residencia hasta su conclusión citación sentencia tasación de costas y en su ausencia y rebeldía le señalo los estrados de mi audiencia y juzgado donde se hagan las citaciones notificaciones de los autos y sentencias que citación y notificación requieran y les parara el perjuicio como si se les hiciera en sus personas y para que llegue y venga a noticia de todos se pregonará este edicto en esta ciudad y las demás de esta gobernación en la forma acostumbrada para lo cual se despachen duplicados de él a las dichas ciudades y publicados se pondrán y fijarán con lista de los residenciados en las puertas de los oficios públicos y ninguna persona sea osada de los quitar 
romper ni borrar pena de cincuenta pesos aplicados por mitad real cámara de su majestad y gastos de residencia y de la publicación y de haberse despachado dichos edictos se pondrá fe y razón al pie de este por el presente escribano de esta residencia por lo que mira a esta ciudad / folio 156v/ y por lo que hace en las demás ciudades por la persona que nombrase el juez comisionario que para este efecto se destina en cada una de ellas y es hecho en esta ciudad de Salta en siete días del mes de diciembre de mil setecientos sesenta y tres años por ante el escribano de esta residencia la que se ha de publicar el día veintidós de enero de mil setecientos sesenta y cuatro.

Balthazar Azebey

Por mandado de su merced

Don Joachín de la Cava

Escribano público y de cabildo de Tarija y esta residencia

Fe de haber remitido los edictos [margen izquierdo]

Yo el infrascrito escribano de esa residencia doy fe y testimonio de verdad a los señores que la presente vieren como hoy día veintidós de enero de este presente año de mil setecientos sesenta y cuatro hice publicar el presente edicto por voz de Francisco López mulato que hizo oficio de pregonero y en altas e inteligibles voces se publicó en las cuatro esquinas de la plaza de esta ciudad en concurso de gente a son de caja y clarín como se acostumbra y se puso una copia de él en las puertas del oficio público con nómina de los residenciados y otra de la misma forma en las puertas del señor juez y para que conste lo puse por diligencia en esta ciudad de Salta en el dicho días mes y año siendo testigo don Antonio Martínez alguacil mayor de esta residencia y don Felix Rodriguez y otra mucha gente de que certifico.

Don Joachín de la Cava Escribano público y de cabildo de Tarija y esta residencia

Fe de haberse pregonado el edicto y haberse puesto en las puertas del oficio con nómina de residenciados [margen izquierdo].

Yo el infrascrito escribano de esa residencia doy fe y testimonio de verdad a los señores que la presente vieren como hoy día de la fecha se despacharon las correspondientes comisiones para las ciudades de Córdoba Santiago del Estero San Miguel del Tucumán La Rioja y Catamarca remitiendo copias de este edicto como consta de otra certificación que se tiene puesta al pie de una auto proveído hoy día de la fecha y para que conste puse la presente en virtud de lo mandado $\mathrm{y}$ es hecho en die de diciembre de mil setecientos sesenta y tres años siendo testigos don Felix Rodríguez y don Pedro Joseph Soto.

Don Joachín de la Cava

Escribano público y de cabildo de

Tarija y esta residencia

B- Bloques de preguntas a partir de los cuales fueron interrogados los testigos en la pesquisa secreta.

Se transcribe el original de Salta que fue remitido - casi en su totalidad- al resto de las jurisdicciones. Se incluyen también algunos testimonios registrados en dicha ciudad.

[Interrogatorio sobre la actuación del gobernador y sus oficiales (Pieza 1, folios 156r-172v)]

Por las preguntas siguientes serán interrogados los testigos por don Balthazar de Azebey juez de residencia y cuentas contra don Juan Victorino Martínez de Tineo del tiempo que fue gobernador de la Provincia del Tucumán contra vuestros tenientes ministros y oficiales del tiempo que lo fue de ella. 
Primeramente si conocen al susodicho y a sus tenientes ministros y oficiales y otras personas durante el dicho tiempo /folio 157v/

2-Y si saben que el dicho corregidor haya dejado de cumplir algunas cartas cédulas y provisiones y ordenanzas e instrucciones de su Majestad o de sus Gobernadores o los decretos que se hayan dado en favor de los indios de oficio o a pedimento de algún indio o repartimiento declarando en particular qué provisiones decretos preguntando por cada capítulo de las Instrucciones que se le dieron para el uso del dicho oficio y en que caso y si han remitido las dichas provisiones /folio $158 \mathrm{r} / \mathrm{y}$ decretos para que no haya efecto el cumplimiento de ellas.

3- Y si saben si el susodicho ha residido el tiempo de su oficio en la dicha Provincia y repartimientos, y si estando ausente de su oficio ha llevado y cobrado su salario y que tanta cantidad.

4- Y si saben que el dicho gobernador ha llevado por razón de su oficio /folio 158v/ más salario del que con él le está señalado digan lo que ha cobrado y de qué cajas.

5- Y si saben que el susodicho y los oficiales que ha tenido han llevado algunos derechos a los indios caciques y principales o comunidades de los repartimientos de la dicha provincia o ha pedido o consentido que los lleven y en qué cantidad y quién y por qué causa y asimismo si han recibido algunas dádivas cohechos y presentes en mucha o en poca cantidad /folio159r/ declarando de qué indios y cuántos Y si saben que el susodicho a la gente de su casa o familia han tomado o servido de alguna persona donación ofreciéndoles algunas cosas o han recibido algunos cohechos y cuáles y cuántos y por ésta razón hayan dejado de administrar justicia y a quien hayan en esto /folio 159v/ agravado.

6-Y si saben que el dicho corregidor o sus oficiales hayan tenido confederación con algunos indios o encomenderos de los dichos repartimientos o contra personas de la dicha provincia y sus términos o con las que han venido a rescatar o contratar a ella, o si de la dicha provincia ha pedido o consentido que los lleven y en qué calidad y por qué causa.

7- Y si saben que el dicho corregidor o sus oficiales hayan tenido confederación con algunos indios o encomenderos de los dichos /160r/ repartimientos, o contra personas de la dicha provincia y sus términos, o con las que han venido a rescatar o contratar a ella, o si de ello ha venido algún perjuicio a los indios y comunidades digan y en qué caso.

8- Y si saben que los susodichos o algunos de ellos por sí o por interpósitas personas han comprado o rescatado algún Heredad es de tierra ganados de los dichos naturales o edificado algunas casas/160v/en la dicha Provincia y partido y hecho sementeras.

9- Y si saben si el susodicho ha introducido más géneros y efectos de los que se le permiten y vendídolos a mayor precio de lo que consta por el Arancel que se le dio en su título.

10- Y si saben que los susodichos o alguno de ellos han ocupado o tenido o pasteado en las tierras y pastos de la dicha provincia.

11- Y si saben que el dicho corregidor ha tenido o tiene alguaciles y tenientes sin orden ni licencia de quien pudo y debió dársela y si los que ha tenido son encomenderos de los /161r/ dichos indios o sus parientes de ellos o del dicho corregidor dentro del cuarto grado o criados $u$ otras personas hayan tenido que daños o agravios han hecho a los indios y tales ministros.

12- Y si saben que el dicho corregidor haya dado lugar a que algunas personas sin tener comisión de su Majestad o de sus Gobernadores hayan usado de su jurisdicción civil y /161v/ criminal en la dicha provincia y repartimientos y en sus términos.

13- Y el dicho gobernador durante el tiempo de su oficio ha visitado los términos de su jurisdicción, ventas y tambos de ellas sin llevar salario por ello como está obligado o de cuanto a 
cuanto tiempo y si ha procurado que las dichas ventas y tambos estén proveídos y abastecidos de lo necesario para los caminantes y sin han puesto aranceles a cuyo cargo han estado.

14- Y si saben que el dicho corregidor haya sido negligente /folio 162r/ en guardar y cumplir lo que cerca de los dichos tambos y ventas está proveído y ordenado, sobre que los dichos tambos estén a cargo de los indios y de que se le paguen los mantenimientos leña y yerba que en ellos se ha dado y dieren y de que estén proveídos los dichos tambos de lo necesario.

15- Y si saben que el susodicho haya consentido ocupar alguna persona en particular las tierras y pastos y pertenecientes /folio 162v/ a los dichos repartimientos con perjuicio de los naturales y no se hayan hecho restituir a los indios dueños de ellas y si han sido remisos en ello.

16-Y si saben que el susodicho o sus ministros hayan llevado algunas dádivas a los naturales de la dicha Provincia y repartimientos y sus encomiendas en ropa ganados o en cosas de comer de pescado gallinas y perdices y otras cualquiera demás del salario que se les daba por su oficio y que las hayan llevado o tomado y comprado en menos precio de lo que valían en comunidad /163r/.

17- Y si saben que el dicho corregidor o sus oficiales hayan llevado o consentido llevar asesorías de vistas de procesos sin primero haber oído los y sentenciado por las sentencias que han dado.

18- Y si saben que el susodicho haya condenado a algunos indios en penas pecuniarias, y las han recibido para sí y para otros efectos que por leyes y ordenanzas no se pueden llevar.

19- Y si saben que por razón / folio 163v/ de llevar las dichas penas o otras por ellos antes de sentenciarlas causas han hecho algunos conciertos o iguales con las partes.

20- Y si saben que los susodichos hayan sido remisos y negligentes en la defensa de la Jurisdicción Real o si la han consentido usurpar y dado lugar a que le sean notificadas cartas de jueces eclesiásticos para se inhibir por ellas, o sin han impedido la Jurisdicción Real, o que hayan aceptado ruego de algunas personas, o algunos escritos para que no haya entero cumplimiento de justicia.

21- Y si han tenido cuidado de hacer reparar y aderezar los caminos y puentes de la dicha provincia y repartimientos /folio 164r/ de su distrito, a cuya costa en que paga y sin han sido negligentes en ello de cuya causa haya resultado algún daño a los indios u otras personas.

22- Y si saben que haya dejando de castigar los pecados públicos así los que han blasfemado de Dios nuestro Señor, o de su bendita madre, u de otros pecados públicos, o dejado de seguir los delincuentes con los que /folio 164v/ hubiesen delinquido en su jurisdicción como a los demás que por cartas de justicia se les hubiere advertido conforme a las leyes que sobre esto disponen.

23- Y si saben que el dicho corregidor haya sido negligente en castigar los amancebados hechiceros perjuros tuantes $(i)$ y sin han consentido que los haya en su distrito y asimismo que en él anden vagabundos, $u$ otras personas de mal vivir que den mal ejemplo.

24-Y si han sido negligentes en inquirir a donde se alojan los delincuentes en su jurisdicción y si sabiendo en donde están no han hecho las diligencias de su obligación / folio165r/ para los prender especialmente en los casados que por particular comisión se les ha mandado.

25- Y si saben que hayan consentido que anden entre los Indios Mestizos, Mulatos y Negros de mal vivir en perjuicio de los naturales y no lo han remediado y castigado.

26- Y si saben que en las dichas provincias y sus términos haya algunas personas que hayan hecho algunos agravios a los indios pobres de ella o a los españoles en quitarles sus haciendas o otras semejantes vejaciones. Y si ha venido a noticia de dicho corregidor y juez y ha sido negligente en no lo remediar y procurar que los in- dios /folio 165v/ sean bien tratados y 
doctrinados en las casa de Nuestra Santa fe católica o si han consentido y dado lugar que se les hiciesen malos tratamientos en sus personas y haciendas.

27- Y si saben que el susodicho y justicias hayan consentido que los oficiales reales encomenderos conmuten algunos tributos a los indios de sus encomiendas a servicio personal /folio 166r/ o en otra manera y que se saquen algunos indios o indias de los repartimientos o pueblos para el servicio de sus casas guarda de ganados a beneficio de sus haciendas o para otras cosas y para cargarlos sin licencia particular y sabiéndolo los susodichos no lo han castigado.

28- Y si saben que dicho corregidor haya guardado y hecho guardar las cédulas provisiones y ordenanzas de su Majestad /folio 166v/ que hablan sobre que no se carguen indios o si los han cargado o consentido que los carguen otras personas y si les han dejado de pagar sus jornales y trabajo en sus propias manos y no por las de sus caciques.

29- Y si saben que el susodicho ha procurado /folio 167r/ que se efectúen y acaben las reducciones que en aquel distrito se ordenó y mandó se hicieren y dado licencia a algún indio o india para que vivan apartados de la dicha reducción y pueblo donde habían de vivir mandando o alterando alguna cosa de la ordenanza y tasa de las dichas /folio 167v/ reducciones sin particular comisión y orden y si ha hecho ejecutar lo proveído por los visitadores como está mandado.

30-Y si han tomado cuentas de las penas de cámara o de justicia o de los bienes de comunidades de los repartimientos de los menores y puesto/folio168r/buen recaudo en la cobranza conservando el buen aumento de ellos y de sus bienes.

31- Y si saben que haya gastado o permitido que se gasten los propios y rentas de bienes de comunidad en la dicha Provisión o repartimientos en cosas que no sea en bien de su república y los han gastado en provecho de dicho corregidor de los sacerdotes caciques o otros indios o personas particulares o hecho gracia / folio $168 \mathrm{v} /$ de ellos o ayudas de costas y para que efectos.

32- Y si saben que el dicho corregidor y ministros hayan tomado para sí o para ellos en arrendamiento las tierras y propios de los dichos repartimientos o sus comunidades obrajes y haciendas.

33-Y si saben que el dicho /folio169r/corregidores o sus oficiales habiendo aplicado algunas condenaciones para la Cámara de su Majestad gastos de justicia y en otra manera se hayan quedado con las dichas condenaciones.

34- Y si saben que el dicho corregidor ha nombrado depositario de las dichas condenaciones y ha tenido libro en que se asienten, o teniéndolo han dejado de asentar alguna de ellas o lo que se ha hecho.

35- Y si saben que en la dicha provincia sus términos y jurisdicción ha habido algunas personas / folio 169v/ que sean casados en los reinos de España, o en otras partes y no los han preso, y enviádolos presos a ellos luego y sin dilación y si han disimulado contra los tales contra lo ordenado por su Majestad y dejádose de efectuar las penas de los tales casados a quien se haya dado licencia hasta aquí.

36-Y si saben que el dicho corregidor por algunos respetos y causas haya dejado de hacer pagar jornales y trabajo /folio 170r/ a los dichos indios de lo que les pertenecía o en otra manera algunas el es debía por algunas restituciones o a sus comunidades o en que particulares.

37-Y si saben que las provisiones de datas de tierras que se le han pedido parecer para darlo ha ido el dicho Corregidor a verlas por su persona y si las hizo publicar juntamente para ello a los indios y cómo se las dio a entender y si siendo en agravio de los dichos indios el dar dichas tierras lo ha disimulado y hecho por mano ajena. 
38- Y si saben que el dicho corregidor sin haber cobrado y hecho meter en la caja de comunidades lo que se le aplica para justicia /folio 170v/ y los demás efectos que por la tasa está ordenado de los indios haya cobrado de salario contra lo proveído por las ordenanzas.

39- Y si saben que el dicho corregidor haya dejado de meter en la dicha caja de comunidad alguna parte de la cobranza de lo aplicado para las dichas justicias, y se haya aprovechado de ello en alguna manera trayendo fuera de ellas y hayan tomado las llaves de los demás llaveros para abrir las cajas sin estar /folio 171r/ presentes como lo manda la ordenanza y provisión que [no se lee].

40- Y si saben que el dicho corregidor haya pagado y hecho pagar a los sacerdotes que residen en las Doctrinas de su distrito los salarios de ellos sin haber tenido presentación y en qué tiempo se les paga y en qué cantidad.

41-Y si saben que las ausencias que han hecho los dichos sacerdotes han descontado de sus salarios y sínodo y si lo ha metido en las cajas de comunidad lo que está monto, como está mandado.

42- Y si han consentido llevar a los dichos sacerdotes camaricos raciones /171v/ servicios y otras cosas que les están prohibidas por las dichas tasas, y no han tenido cuidado de lo pagar a los indios de lo tocante a sínodo del salario del dicho sacerdote.

43-Y si el dicho corregidor y sus ministros han tomado a los dichos indios de su distrito algunas cosas de las que dan de sus tributos con baja de los precios de la tasa y especialmente los carneros de la tierra y otras cosas en que hayan tenido o tienen granjerías o en las almonedas que han hecho de las dichas especies las han sacado para sí por interpósitas personas, o en otra manera. / folio $172 \mathrm{r} /$

44- Ítem se ha de preguntar a los testigos por los capítulos de las mismas instrucciones que tuvo y se le dieron para el orden de administrar justicia y ejercicio de dicho oficio.

45- Ítem si todo lo susodicho es pública voz y fama: fecho en Los Reyes en tres de octubre de mil setecientos sesenta y uno años.

[Cuestionario sobre la actuación del gobernador y sus oficiales, agregado por Balthazar Azebey para la ciudad de Salta (Pieza 1, folios 172v-174v)]

Nuevo interrogatorio [al margen]

En la ciudad de Salta en diecinueve días del mes de enero de mil setecientos sesenta y cuatro años su Merced el señor don Balthazar de Azebey juez privativo de cuentas y residencias que debe dar el señor coronel don Juan Victorino Martínez de Tineo del tiempo que fue gobernador en esta Provincia del Tucumán y sus tenientes cabildos jueces ministros y oficiales y comprendidos en dicho tiempo por especial comisión de su majestad (que dios guarde). Dijo que en atención a dársele facultad para crecer el interrogatorio de su Excelencia las demás preguntas que fuesen necesarias para la mayor averiguación del proceder del gobernador y de todos los demás residenciados en cumplimiento de los cargos que habían ejercido en consecuencia de lo cual se habían actuado los correspondientes interrogatorios y restaba hacer otro ajustado a esta Provincia y al proceder que debió tener dicho señor Gobernador como bueno y vigilante ministro de su Majestad que Dios guarde así por ser en bien del común como el aumento de su Real Hacienda debía mandar y mando que los testigos que en dicha información y pesquisa secreta hubiesen de declarar se les pregunte al contexto del interrogatorio que remitió su Excelencia como al de la Instrucción que se le dio a dicho Goberna /folio 173v/ dor para su inteligencia y además de ellas por el tenor del interrogatorio siguiente. 
1- Primeramente si saben que dicho gobernador hubiere llevado por los autos sentencias $u$ otras actuaciones que ante ellos pasaron más derechos que los prevenidos en el Real arancel o si consintieron que sus escribanos o demás oficiales lo hiciesen digan.

2- Ítem si saben que el dicho gobernador hubiese tenido más tenientes que los acostumbrados y si los que tuvo fueron confirmados por real acuerdo y concurrieron en ellos la calidad que correspondía para este efecto digan.

3- Ítem si saben que el dicho gobernador en su tiempo nombró algunos jueces de comisión y si estos hicieron algunos daños y por ello no fueron castigados digan.

4- Ítem si saben que dicho gobernador hubiese sido remiso en tomar las cuentas de propios de esta ciudad. Y si habiéndolas tomado dejaron de ejecutar por los alcances y si permitieron que dichos propios y rentas se gastasen en cosas que no fuesen en pro y utilidad de ellas y del bien común digan.

5- Ítem si saben que dicho gobernador en los negocios tocantes a la real hacienda y por muerte o ausencia de cualquiera oficial de esta ciudad han cuidado del buen cobro del real haber teniendo la llave en su poder y dado cuenta con pago /folio 174r/ de lo que fue a su cargo digan.

6- Ítem si saben que dicho gobernador fue remiso en hacer y dar audiencia pública en los estrados que están dispuestos para ello para que las partes concurran a pedir su justicia con libertad y si han hecho audiencia en su casa en partes ocultas y si han tratado mal a algunos pleitantes de obras o de palabras y los daños que de esto han resultado digan.

7- Ítem si saben que en esta provincia haya algunas minas de plata o oro y si el dicho gobernador tuvo tratos con azogueros o mineros comprándoles la plata en pasta piñas o planchas por menos precio y extraviando lo que compraba por lo que fueron disminuidos los reales cuentos que pertenezcan a su majestad digan.

8- Ítem si saben que dicho gobernador hubiese permitido o disimulado que otras personas comprasen o res- catasen marcos de plata o oro de la provincia y no los llevasen a rescatar antes si los extraviasen en perjuicio de su majestad declaren quién y qué cantidades y si celaban que los mineros y rescatios de plata de esta provincia fuesen rescatarla a la villa de Potosí a las reales cajas de esta ciudad digan.

9- Ítem si saben que dicho gobernador haya hecho algunas condenaciones o impuesto multas en los litigios que ante él se hayan seguido o sin contestatación de juicio o con algún otro mantuvo declaren qué cantidades y a quiénes y en qué forma las aplicaron. /174v/

10- Ítem si saben que dicho gobernador no siendo como no es letrado en algunos negocios haya seguido el parecer que evidentemente era injusto y si han sentenciado algunas causas graves sin parecer de asesor digan.

11- Ítem si saben que dicho gobernador sus tenientes $u$ otro juez hayan cometido alguna fuerza contra alguna mujer o vivido escandalosamente o entrado a tratar con ella socolor de administrar sus oficios o con otro pretexto digan.

12- Ítem si saben que cosas notables y bien hechas hubiese hecho el citado gobernador y sus tenientes en sus oficios en servicio de su majestad bien de esta ciudad y provincia y de los vecinos y particulares de ella declaren que cosas digan.

13- Ítem de público y notorio digan.

Por las cuales dichas preguntas y por todas ellas mando su merced que se examinasen los testigos de la información y pesquisa secreta contra el dicho Gobernador así lo proveyó mandó y firmó de ello doy fe. 
Balthazar Azebey

Ante mí

Don Joachín de la Cava Escribano público y de cabildo de Tarija y esta residencia

[A continuación se agrupan las declaraciones de los testigos sobre los oficios examinados]

[...]

[Testimonio de don Manuel de Aballe (Pieza 1, folios 207v-212v),registrado en el marco de la pesquisa secreta seguida en la ciudad de Salta]

$7^{\circ}$ [al margen, refiere al séptimo testigo]

En la dicha ciudad día mes y año dichos [26 de enero de 1764] /folio 208r/ su merced dicho señor juez privativo de cuentas y residencia para la citada información y pesquisa secreta que está recibiendo sobre los hechos y procedimientos del señor coronel don Juan Victorino Martínez de Tineo por el tiempo que fue gobernador de esta provincia mandó comparecer ante sí y en su juzgado a don Manuel de Aballe vecino de esta ciudad a quien yo el escribano de esta residencia por su mandado y en su presencia le recibí juramento que hizo por Dios nuestro señor y una señal de cruz según forma de derecho so cargo del cual prometió decir verdad de lo que supiere y fuere preguntado y siéndolo al tenor de la instrucción que remitió su Excelencia al dicho gobernador [refiere a las instrucciones dadas a Tineo al momento de asumir su cargo] y asimismo del interrogatorio que envió para el efecto de esta residencia y del nuevamente hecho por su merced habiéndole encargado el sigilo que corresponde.

$1^{\text {a- }}$ Primeramente dijo que conoció al señor coronel don Juan Victorino Martínez de Tineo y lo vio ejercer el citado oficio de Gobernador de esta Provincia que no le tocan las generales de la ley que tiene noticia de esta residencia y es de edad de cuarenta y ocho años y responde.

$2^{\mathfrak{a}-}$ A la segunda pregunta dijo que había guardado el dicho señor Gobernador todas las cédulas provisiones y mandatos $\mathrm{su} / 208 \mathrm{v} /$ periores en razón de indios bien y cumplidamente sin faltar en cosa alguna y responde.

$3^{3}$-A la tercera pregunta dijo que el dicho gobernador el tiempo que ejerció dicho empleo se había mantenido en esta provincia sin hacer ausencia alguna y responde.

$4^{\text {a- }}$ A la cuarta pregunta dijo que el dicho gobernador había llevado el salario que se le tiene asignado sin excederse en manera alguna y que se le había pagado de las reales cajas de su majestad de la ciudad de Jujuy y responde.

5- A la quinta pregunta dijo que no había sido que el dicho gobernador hubiese llevado derechos algunos a los caciques gobernadores ni indios como ni tampoco dádivas presentes ni cohechos algunos y responde.

6 y 7-A la pregunta sexta y séptima dijo que no sabe cosa alguna.

8- A la octava pregunta dijo que le constaba a este declarante y era público y notorio que el dicho gobernador en el citado tiempo no compró ningunas heredades tierras ni ganados algunos de los naturales ni /folio 209r/ de otras personas ni edificios casas algunas en esta ciudad ni en su provincia y república.

9 y 10- A la novena y décima pregunta dijo que no introduje el susodicho gobernador efectos algunos a esta provincia y en cuanto a ganados o daños que hubiese hecho con ellos se remite a lo que tiene dicho de que no tuvo algunos y responde.

11- A la pregunta once dijo que no sabía que hubiese nombrado alguacil ninguno ni tampoco más tenientes que los que eran permitidos y responde. 
12- A la pregunta doce dijo que no sabía que el dicho gobernador hubiese consentido administrar jurisdicción civil y criminalmente a ninguna persona que no tuviese comisión suficiente y responde.

13, 14 y 15-A la pregunta trece catorce y quince dijo que en esta provincia no había ventas ni tambos ni tampoco tierras de repartimiento por lo que no puede decir sobre su asunto cosa alguna y responde.

16 y 17- A la pregunta dieciséis y diecisiete dijo que no sabía cosa alguna sobre su /folio 109v/ asunto y responde.

18 y 19- A la pregunta dieciocho y diecinueve dijo que no sabía que el dicho gobernador hubiese llevando ni condenado a ningún indio en penas pecuniarias ni antes ni después de sentenciar sus causas ni hecho concierto ni igualdad con ningunas personas de que se siguiese perjuicio a los naturales y responde.

20- A la pregunta veinte dijo que el dicho gobernador había siempre defendido la real jurisdicción como era obligado sin consentir que se le intimasen ningunas cartas ni descomuniones por los eclesiásticos para inhibirle de su jurisdicción y responde.

21-A la veintiuna pregunta dijo que el dicho gobernador había sido solícito y puesto toda atención en reparar los caminos hacer aderezar los puentes de esta ciudad y que puso en el río que pasa cerca de esta ciudad un reparo sólo a fin de que no entrase a perjudicar esta ciudad y que parte había sido a costa de los cortos propios y parte no tiene fijeza quien fue el que lastó de su peculio y responde.

22, 23 y 24- A la pregunta veintidós, veintitrés y veinticuatro dio que el dicho gobernador había puesto atención en castigar los pecados públicos e inquirir en la parte que estaban los /210r/ vagabundo y personas de mal vivir para echarlas de su jurisdicción y darles el castigo que correspondía a su mal ejemplo y responde.

25 y 26- A la pregunta veinticinco y veintiséis dijo que en esta provincia los indios eran muy pocos y estos estaban entre los mestizos mulatos y negros pero que el dicho gobernador siempre tuvo particular cuidado de que no hiciesen a los dichos naturales perjuicio alguno ni permitido que a ellos ni a españoles pobres les quitasen bienes o hiciesen extorsiones porque aplicó en esto todo cuidado y responde.

27 y 28- A la pregunta veintisiete y veintiocho dijo que no sabe cosa alguna sobre su asunto ni oyó de porque a los indios de encomienda los hubiesen castigado ni hecho vejación alguna y responde.

29-A la pregunta veintinueve dijo que era constante y le constaba a este declarante de vista y experiencia que el dicho gobernador fue insaciable en poner todo ahínco y esfuerzo en las reducciones de los Bárbaros Infieles de esta frontera que al tiempo que entró se hallaba tan invadida practicando robos, muertes y tenía tan sobresaltada esta Provincia que era una total e inexpli /folio 210v/ cable lamento de todos los morados y vecinos de ella y con las muchas entradas y corridas que personalmente hizo llegó a atemorizar a los indios infieles y redujo las naciones tobas: lules: malbalaes: abipones: isistenes y mocobíes reduciéndolos a que estuviesen en población formal para lo que les mandó hacer ranchería para ellos y casa para los capellanes; sus iglesias muy decentes en las que se doctrinaba e instruía en los misterios de nuestra santa fe. Puso varios fuertes y piquetes para el resguardo y seguridad de esta frontera bien pertrechados de armas y municiones unos fortificados de cimientos y pared y otros de maderas mantuvo en ellos los partidarios que correspondían pagándoles su trabajo para conversión de dichos infieles y para atraerles las voluntades les dio ropa y otros varios efectos y continuamente los bastimentos de carne pues en una ocasión llevó toda la carne de castilla que tenía en esta ciudad para su gasto 
la llevo para tener gratos a los Indios: Pobló dos estancias de Ganado Vacuno para que /folio $211 \mathrm{r} /$ con el aumento sirviese para los partidarios y para dichos Indios y en fin a todo el celo y anhelo que tuvo sobre este asunto se debe el que esté esta Provincia con el sosiego paz y descanso que se goza y responde.

30, 31 y 32- A la pregunta treinta treinta y uno y treinta y dos dijo que no sabía que hubiese tomado cuentas de propios y en cuanto a bienes de comunidad dijo que había de esta especie en esta provincia y responde.

33 y 34- A la pregunta treinta y tres y treinta y cuatro dijo que no sabía cosa alguna y responde.

35- A la pregunta treinta y cinco dijo que no sabía cosa alguna y responde.

36- A la pregunta treinta y seis dijo que había puesto todo cuidado el dicho gobernador en que se pagase a los indios su trabajo sin permitir que por esta razón recibiesen perjuicio alguno y responde.

37, 38 y 39-A la pregunta treinta y siete y treinta y ocho y treinta y nueve dijo que no sabe otra cosa que en esta provincia no había bienes /211v/ de comunidad y responde.

40, 41 y 42- A la pregunta cuarenta cuarenta y una y cuarenta y dos dijo que no cosa alguna como tampoco a la pregunta cuarenta y tres y responde.

Y siendo examinado al tenor de la instrucción remitida por su Excelencia para su gobierno dijo.

A la primera que tiene por cierta que dio fianzas el dicho gobernador antes de entrar al ejercicio de dicho empleo y fue recibido en la ciudad de Córdoba donde cree que haría el juramento de guardar fidelidad y responde.

2- Al segundo capítulo dijo que le constaba que luego que el dicho gobernador entró a su empleo habían cesado los tenientes generales de esta jurisdicción y entraron los que nuevamente nombró y en las que no hizo nombramientos de tenientes destinó y dio título de gobernadores de armas para que se tuviese en cuanto a milicia siempre todo cuidado y responde.

3- A la tercera pregunta dijo que había hecho el dicho gobernador buen tratamiento de los indios y que había conocido en todas las causas civil y criminalmente en primera y segunda instancia y conce /folio 212r/ dió las apelaciones que se habían interpuesto siendo según derecho.

4- A la cuarta pregunta dijo que nunca había obligado a los indios a que le diesen bastimentos ni bagajes las veces que había salido y responde.

5, 6,7 y 8- Al quinto, sexto, séptimo y octavo capítulo dijo que en cuanto a reducciones se remitía a lo que tiene dicho y en cuanto a los demás capítulos dijo que le constaba que el dicho gobernador había puesto igual aplicación y celo en poner guardas y espías para que no transitasen los géneros de ilícito comercio como tampoco que pasasen piñas de plata ni oro sin que estuviesen quintados y que igual celo puso en que no saliesen efectos de toda esta provincia de los sujetos apagaricia [sic] sin que contribuyesen lo que se haya destinado lo que es público y notorio.

9- A la novena pregunto dijo que en esta provincia no se había verificado el que se plantificase el estanco de tabacos y responde.

Y habiendo sido examinado este declarante por el interrogatorio hecho por su merced.

A la primera pregunta dijo que no sabía cosa alguna y responde.

Desde la segunda hasta la décima pregunta dijo que sólo sabía de ellas que el citado gobernador dio audiencia en las casas de su morada /folio $212 \mathrm{v} /$ como era costumbre y que no hizo maltrato 
de los litigantes ni los trató de malas palabras ni obras sino que distribuyó justicia conforme era obligado y responde.

A la pregunta once dijo que no sabía cosa alguna sino que se había portado el dicho gobernador con mucho recato y ejemplo como era público y notorio y responde.

A la pregunta doce dijo que se remite a lo que tiene dicho.

A la pregunta trece y última dijo que todo lo que lleva dicho es público y notorio pública voz y fama y es la verdad del juramento que hecho tiene en que se afirmó y ratificó y que lo volverá a decir cada [vez] que convenga y habiéndole leído su declaración dijo estar bien escrita que no tiene que añadir ni quitar y lo firmó con su merced de ello doy fe. [sigue una enmienda que en esta copia ya hemos incorporado a la versión trascripta]

Balthazar Azebey Manuel de Aballe Ante mí

Don Joachín de la Cava Escribano público y de cabildo de Tarija y esta residencia

[Continúan los testimonios del resto de los testigos] [...]

[Interrogatorio sobre la actuación de los miembros del cabildo (Pieza 2, folios 63r-64v)]

Para el cabildo [margen izquierdo arriba]. Para salta [margen izquierdo arriba].

Por las preguntas siguientes serán examinados los testigos que han de declarar contra el cabildo justicia y regimiento fieles ejecutores y demás que tienen voto en él es a saber el Alcalde Provincial don Joseph Cabrera, el fiel ejecutor y regidor don Francisco de Toledo el Alférez Real don Joseph de Arias Rengel regidores que fueron en esta ciudad de Salta el tiempo que fue gobernador el señor coronel don Juan Victorino Martínez de Tineo por la forma y manera siguiente.

1- Primeramente si conocen a los contenidos y durante el tiempo de sus oficios los vieron ejercer sus empleos si tienen noticia de esta causa y las generales de la ley.

2- Ítem si saben cómo y de qué suerte han ejercido dichos regidores sus oficios y si saben que hayan hecho los cabildos ordinarios que tienen obligación hacer en cada un año para tratar del beneficio de esta ciudad y si han faltado a esto por cuya causa lo han dejado de hacer digan.

3-Ítem si saben que los dichos regidores han hecho merced de algunas tierras o estancias aplicándolos para los propios de la ciudad contra ordenanzas digan.

4- Ítem si saben que los dichos regidores y personas que tienen voto en cabildo en las elecciones que /63v/ se hacen en principio de un cada año de alcaldes ordinarios de la hermandad y otros oficios no han guardado lo que se manda por leyes de estos Reinos nombrando personas que no sean suficientes para obtener dichos empleos o dando sus votos por cohecho o otros intereses digan.

5- Ítem si saben que dichos regidores o algunos de ellos han tenido trato de recatonería de mantenimientos o hecho vender su pan, vino o carne o otros efectos de esta clase a más precio del conveniente o permitido que otros lo vendan y no lo han remediado digan.

6-Ítem si saben que dichos regidores o alguno de ellos no ha guardado el secreto que se manda conforme a decreto y el juramento que tienen hecho y si alguno ha revelado el secreto de lo que se trató y debió guardar digan.

7- Ítem si saben que dichos regidores o alguno de ellos ha tenido sus ganados en pastos de los vecinos o si les han hecho algún otro daño digan.

8- Ítem si saben que el fiel ejecutor ha visitado las carnicerías y pulperías y puesto aranceles conforme al tiempo y necesidad y si a las personas que han excedido de dichos aranceles han sido 
castigadas o si se les disimuló o si dicho fiel ejecutor ha tenido trato y granjería con los pulperos ganaderos y carniceros digan.

9- Ítem si saben que dichos regidores o fiel ejecutor por razón de administrar sus oficios han recibido dádivas cohechos o presentes de los vecinos o forasteros/64r/por que no los castigan digan.

10- Ítem si saben que dichos regidores han tenido casa de juegos prohibidos consintiendo se jueguen en ella cantidad de pesos por coima o por otro interés y si han permitido que los jugadores blasfemas en el nombre del Dios o sus santos digan.

11- Ítem si saben que dicho fiel ejecutor como está ordenado ha visitado las tiendas y mercancías en cada un año reconociendo y sellando la vara y cuidando que los pesos y medidas esté con los de la ciudad igualada y si en cuanto a sus derechos se han arreglado a las ordenanzas del señor Toledo, o si han llevado sin practicar dicha visita los derechos digan cuanto y si cuando hallaban el peso o vara no corriente lo castigaban y recogían los pesos para que usasen corrientes y sellados digan.

12-Ítem si saben que dicho fiel ejecutor no ha tenido cuidado en que las calles y plazas estén limpias y reparadas como está obligado digan.

13- Ítem si saben que los regidores hayan cuidado con vigilancia que en cada un año se saque el pendón real en reconocimiento del vasallaje que debemos conocer a Nuestro Rey y Señor y si ha sido con el acompañamiento veneración y respeto que se debe y si no habiendo alférez real se ha observado que lo saquen los regidores por turnos y su secuela como está ordenado digan.

14-Ítem si todo lo que saben es público y notorio pública voz y fama digan.

Habiendo visto este interrogatorio de preguntas contra el cabildo y regimiento de esta ciudad /64v/ el Señor Juez Privativo de esta Residencia mandó que por su tenor se examinasen los testigos que hubiesen de declarar en la pesquisa secreta y se le encargue el secreto que se debe guardar así lo proveyó mandó y firmó de ello doy fe.

Balthazar Azebey

Ante mí

Don Joachín de la Cava Escribano público y de cabildo de Tarija y esta residencia

[A continuación se agrupan las declaraciones de los testigos sobre el oficio examinado]

$[\ldots]$

[Interrogatorio sobre la actuación de los alcaldes ordinarios (Pieza 2, folios 108r-109v)]

Interrogatorio para Alcaldes ordinarios [arriba centrado].

Por el tenor de este interrogatorio serán examinados los testigos que declarasen en la pesquisa secreta sobre los hechos y procedimientos de los alcaldes ordinarios de esta ciudad de Salta es a saber ... [sigue el listado de los que ejercieron dicho oficio durante el mandato de Tineo]

1- Primeramente si conocen a todos los susodichos y los vieron ejercer dichos empleos y si tienen noticia de esta residencia y generales de la ley.

2-Ítem si saben cómo y de qué suerte los dichos Alcaldes Ordinarios han administrado /108v/ justicia a las personas que ante ellos la han pedido y si en administrarla han sido remisos y negligentes y si han dejado de cumplir algunas cartas de nuestro Rey y Señor su Real Audiencia y Virrey y si han residido al tiempo de sus empleos en la ciudad si han hecho ausencia y por ella ha resultado perjuicio a los delincuentes digan cual. 
3-Ítem si saben que los dichos Alcaldes por razón de sus oficios han llevado más derechos de los que se le debían y si han recibido algunas dádivas cohechos o presentes de algunas personas digan.

4-Ítem si saben que los dichos Alcaldes han sido remisos en castigar los pecados públicos amancebamientos hechiceros adivinos alcahuetes juegos prohibidos reniegos blasfemias usuras hurtos y otros semejantes habiendo tenido noticia de algunas personas que han cometido algunos de los dichos delitos han disimulado con ellos y no los han castigado digan.

5- Ítem si saben que dichos Alcaldes o alguno de ellos han llevado alguna cosa de las penas de cámara y otras que disponen las leyes de estos reinos sin primero haber sentenciado las causas y oído a las partes y pasado a sentencia de cosa juzgada digan.

6-Ítem si saben que dichos Alcaldes no han /109r/rondado por cuya causa el tiempo que han tenido sus oficios se han hecho y cometido en la ciudad muchas muertes robos y otros delitos y de ellos han quedado los delincuentes sin castigo, y si han sido negligentes en no prender los hombres delincuentes y no permitir en la ciudad ni en su jurisdicción a los casados en España digan.

7- Ítem si saben que los dichos Alcaldes se han excedido en alguna cosa de la jurisdicción ordinaria, y si han sido remisos en conservarla y defenderla y si durante sus oficios hubieron malos tratamientos de obras o de palabras a las personas delincuentes o que no lo fueren digan.

8- Ítem si saben que dichos Alcaldes han tenido cuidado de despachar con brevedad las causas particularmente la de los presos y sino por no haberlo hecho han sido molestados y aumentádoseles los daños y las costas digan.

9- Ítem si saben que dichos Alcaldes en los cabildos de elecciones que se han hecho al principio de cada un año han guardado las leyes y ordenanzas que son obligados eligiendo personas de las calidades prevenidas y para ello ha sido con los regidores que corresponde y sino habiéndolos se han nombrado las personas que dispone la ordenanza del Señor /109v/ Toledo digan.

10- Ítem de público y notorio de pública voz y fama digan todo lo que supieren.

Y habiendo visto este interrogatorio su merced el señor juez de esta Residencia mandó que por su tenor sean examinados los testigos que declarasen en la pesquisa secreta encargándoles que guarden el sigilo que está ordenado así lo proveyó mandó y firmó en esta ciudad de Salta en siete días del mes de diciembre de mil setecientos sesenta y tres años de ello doy fe.

Balthazar Azebey

Ante mí

Don Joachín de la Cava Escribano público y de cabildo de Tarija y esta residencia

[A continuación se agrupan las declaraciones de los testigos sobre los oficios examinados]

$[\ldots]$

[Interrogatorio sobre la actuación de los alcaldes de la santa hermandad (Pieza 2, folios $128 \mathrm{r}-129 \mathrm{r})$ ]

Interrogatorio para Alcaldes de la hermandad de Salta [arriba centrado].

Por el tenor de las preguntas de este interrogatorio serán examinados los testigos que han de declarar en la pesquisa secreta sobre los hechos y procedimientos del Alcalde Provincial don Joseph Cabrera y los demás alcaldes de la hermandad que ejercieron dicho oficio siendo gobernador de esta provincia el señor coronel don Juan Victorino Martínez de Tineo que lo fueron: ... [sigue el listado de los residenciados] 
1-Primeramente si conocieron a los susodichos en el uso de sus oficios noticia de esta residencia y generales de la ley digan.

2- Ítem si saben que los dichos alcaldes han excedido de su jurisdicción conociendo causas que son de los ordinarios y no de hermandad digan.

3- Ítem si saben que los dichos alcaldes, y /folio 128v/ cualquiera de ellos, han usado sus oficios bien y fielmente, saliendo a correr la tierra y comarca de la ciudad. Y si han sido negligentes ellos, y sus cuadrilleros en prender los delincuentes que han cometido casos de hermandad digan.

4- Ítem si saben que los dichos alcaldes han recibido dádivas, presentes y cohechos de algunos delincuentes, parientes y amigos por cuya causa han dejádolos de prender y castigar.

5-Ítem si saben que los dichos alcaldes han hecho procesos, y autos en la ciudad o su jurisdicción ante personas que no son escribanos públicos ni reales nombrándoles y dándoles título para ello digan.

6- Ítem si saben que por no salir los dichos alcaldes a correr la tierra se han cometido muertes hurtos robos, y salteamientos así de españoles como de indios, y aunque han sabido de algunos delitos que se han cometido contra su jurisdicción no han castigado los delincuentes de que ha venido gran daño, y perjuicio a la ciudad.

7- Ítem si saben que los dichos alcaldes el tiempo que usaron sus oficios, tuvieron cárceles privadas en las casas de su morada así en esta ciudad como fuera de ella teniendo en ellas los presos contra quienes procedían, y en ellas han dado tormentos, y hecho otras diligencias digan.

8- Ítem de público, y notorio pública voz, y fama digan todo lo que supieren. /folio 129r/

Y habiendo visto este interrogatorio su merced el señor juez de esta Residencia mandó que por su tenor se examinen los testigos que fuesen interrogados en la pesquisa secreta encargándoles el sigilo que se debe. Así lo proveyó mandó y firmó en esta ciudad de Salta en doce de diciembre de mil setecientos sesenta y tres años por ante mí el escribano de esta residencia de ello doy fe.

Balthazar Azebey

Ante mí

Don Joachín de la Cava Escribano público y de cabildo de Tarija y esta residencia

[A continuación se agrupan las declaraciones de los testigos sobre los oficios examinados]

$[\ldots]$

[Interrogatorio sobre la actuación de los alguaciles mayores y sus tenientes (Pieza 2, folios 140r-141r)]

Interrogatorio para alguacil mayor y su lugarteniente [margen izquierdo arriba].

Por el tenor de este interrogatorio de preguntas serán examinados los testigos que fueren interrogados en la pesquisa secreta contra los alguaciles mayores y sus tenientes que constasen en la nómina dada y sacada del libro capitular de cada ciudad de la provincia del tiempo que fue gobernador de ella el señor teniente coronel don Juan Victorino Martínez de Tineo a saber.

1- Primeramente si conocían a los susodichos; noticia de esta residencia y generales de la ley digan.

2- Ítem si saben que los dichos alguaciles mayores y sus tenientes han llevado más derechos de aquéllos que le son permitidos en el real arancel y si han recibido cohechos dádivas y presentes digan. 
3- Ítem si saben que los dichos alguaciles mayores o sus tenientes han preso algunas personas sin mandamiento de jueces; y teniéndolo no las han preso y disimulado con ellas digan.

4- Ítem si saben que yendo los dichos alguaciles mayores o sus tenientes en compañía de algún juez a prender algún delincuente le han enviado a avisar para que se huya, y ponga en cobro por cuya causa han quedado sin castigo digan.

5- Ítem si saben que los dichos alguaciles mayores /folio 140v/o sus tenientes no han rondado de noche la ciudad como son obligados por cuya ocasión ha habido robos muertes y se han cometido otros delitos en daño de los vecinos y moradores, y demás personas digan.

6-Ítem si saben que el dicho alguacil mayor y sus tenientes entraban en las casas de juegos de naipes dados y otros juegos prohibidos, y por los baratos que les daban no denunciaban de ellos ni de los coimeros y jugadores por cuya causa nunca fueron castigados digan.

7- Ítem si saben que los dichos alguaciles han estado amancebados, y por estarlo ellos han consentidolo estén otras personas no denunciando de ellas para que la justicia remediase digan.

8- Ítem si saben que los alguaciles mayores o sus tenientes cuando le han dado mandamiento de ejecución fuera de la ciudad han llevado derechos de leguas y de ejecución antes de estar pagadas las partes ni hacer tasación de costas digan.

9- Ítem si saben que habiéndose hallado dichos alguaciles en alguna pendencia pudiendo prender a los delincuentes no lo han hecho por cuya causa se han quedado sin castigo y si las armas que han quitado no las han manifestado ni denunciado de ellas, y sin serles adjudicadas por las justicias se han quedado con ellas digan.

10- Ítem si saben que el dicho alguacil mayor y sus tenientes por sí o por otras personas han arrendado los propios de la ciudad y tenido parte /folio 141r/ en ellos y otros tratos y granjerías o si arrendó la alcaidía de la cárcel pública y varas de los que usaban oficios de sus tenientes contra viniendo a lo dispuesto por leyes del reino o si han dado títulos de tenientes, y sin presentarlos ante la justicia ordinaria han usado los dichos oficios digan.

11- Ítem si saben que los dichos alguaciles mayores o menores antes de la queda han desarmado a alguna personas, o si le han tocado antes de la hora asignada digan.

12- Ítem si saben que los dichos alguaciles mayores continuamente han rondado la cárcel y prisiones que tienen puestas lo reos o si por no saber ejecutar esto ha habido fugas expresen cuantas y qué reos o de que causas estaban presos y por qué partes han sido dichas fugas digan.

13- Ítem de público y notorio pública voz y fama: digan lo que supieren.

Y habiendo visto este interrogatorio su merced el señor juez de esta Residencia que por su tenor se examinen los testigos que declarasen en la pesquisa secreta encargándoles el secreto que corresponde. Así lo proveyó mandó y firmó en esta ciudad de Salta en siete días del mes de diciembre de mil setecientos sesenta y tres años de ello doy fe.

Balthazar Azebey

Ante mí

Don Joachín de la Cava Escribano público y de cabildo de Tarija y esta residencia

[A continuación se agrupan las declaraciones de los testigos sobre los oficios examinados]

$[\ldots]$

[Interrogatorio sobre la actuación de los procuradores generales y defensores de menores (Pieza 2, folios 160r-160v)] 
Interrogatorio para procuradores generales y defensores de menores [margen izquierdo arriba].

Por el tenor de las preguntas de este interrogatorio serán examinados los testigos que han de declarar en la pesquisa secreta sobre los procedimientos de los procuradores generales y defensores de menores que fueron en el tiempo que ejerció el empleo de gobernador de esta provincia el señor coronel don Juan Victorino Martínez de Tineo, y son [...] [sigue lista de residenciados para esos dos oficios].

1- Primeramente si conocieron a todos los susodichos y los vieron ejercer dichos empleos. Noticia de la residencia, y generales de la ley digan.

2- Ítem si saben que dichos Procuradores generales de esta ciudad han usado bien y fielmente sus oficios, a servicio de Dios, y su majestad y al bien público no consintiendo cosa en perjuicio de la república ni permitiendo que caballero ni otra persona usurpe los términos de esta ciudad, y su jurisdicción ni otra cosa, tocante a los propios de ella, y si sobre ello han hecho /folio 160v/ para estorbar todo lo perjudicial o si lo han dejado de hacer por odio amor o temor digan.

3- Ítem si saben que los Defensores de Menores usaron bien y fielmente sus oficios celando que se hiciesen inventario de los bienes que les pertenecían, y procurando que estuviesen depositados en personas seguras, y de entera satisfacción, y si cuidaron de que diesen cuentas de los frutos que producían, y se hiciesen las particiones sin dolo ni fraude alguno digan.

4- Ítem de público y notorio pública voz y fama digan todo lo que supieren.

Y habiendo visto su merced este interrogatorio mandó que por su tenor sean examinados dichos testigos y se les encargue el sigilo. Así lo proveyó mandó y firmó de ello doy fe en esta ciudad de Salta en doce días del mes de diciembre de mil setecientos sesenta y tres años.

Por su mandado.

Balthazar Azebey

Don Joachín de la Cava

Escribano público y de cabildo de

Tarija y esta residencia

[A continuación se agrupan las declaraciones de los tes- tigos sobre los oficios examinados]

$[\ldots]$

[Interrogatorio sobre la actuación de los escribanos (Pieza 2, folios 168r-169v)]

Interrogatorio para los escribanos de Salta [margen izquierdo arriba]

Por el tenor de este interrogatorio serán examinados los testigos que declararen contra los escribanos [...] [sigue lista de residenciados para esos dos oficios].

1-Primeramente si conocen a los susodichos y tienen noticia de la residencia, y generales de la ley digan.

2- Ítem si han usado bien y fielmente sus oficios o cometido alguna falsedad en él y si ha resultado algún daño a tercera persona digan.

3- Ítem si saben que hayan llevado salarios de iglesia o monasterios o por ejecuciones de penas de cámara o causas de pobres de solemnidad y si han tenido libro en que se asienten los depósitos digan.

4- Ítem si saben que los procesos civiles como criminales ventas poderes y escrituras han dejado de asentar los derechos /folio 168v/ que hayan llevado ellos o las justicias y firmándolo de su nombre digan. 
5- Ítem si saben que en cada un año hayan hecho registros donde estén las escrituras y demás instrumentos públicos y que ante ellos hayan pasado juntos y encuadernados de modo que no se pierda ninguno y si saben que por no haber practicado esto se haya perdido alguna escritura y por ello haya venido daño a las personas o partes digan cual.

6- Ítem si saben que al fin de cada un año haya asignado el registro que hubiese hecho digan.

7-Ítem si han encubierto alguna denuncia o proceso que ante ellos se hayan hecho por algún precio que por ello se les haya dado, y por ello han resultado daño a las partes o la real hacienda digan.

8- Ítem si han llevado más derechos que lo que se mandan por reales aranceles o si han fiado algún proceso a los litigantes y se perdió alguna foja escrita por no haberlos numerado o nació por esta causa algún otro perjuicio digan.

9- Ítem si han hecho algunas escrituras por minuta otorgándola en blanco y después la llenasen en su casa no estando presentes las partes digan.

10- Ítem si saben que los dichos escribanos en el tiempo que han usado sus oficios han /folio $169 \mathrm{r} /$ hecho algunos agravios molestias, y vejaciones a las personas que ante ellos han tenido pleitos no les despachando reteniéndoles sus causas y por este motivo les ha venido daño digan.

11- Ítem si saben que dichos escribano no han asistido al oficio público por cuya causa los pleitos se han dilatado de que ha venido daño a las partes digan.

12- Ítem si saben que los dichos escribanos habiéndoseles encargado el secreto de algunas escrituras o causas que ante ellos han pasado lo han descubierto, y si han recibido dádivas presentes cohechos de oro plata sedas o otras cosas de las personas que ante ellos han tenido negocio para que le sean favorables y si han favorecido por esto o otras causas más a unas partes que a otras siendo sus procuradores y defensores haciéndoles peticiones aconsejándoles lo que han de hacer digan.

13- Ítem si saben que los dichos escribanos han retenido algunos procesos y escrituras sin las querer dar a las partes de que les han venido daño y perjuicio y se han arrendado o tenido parte en las rentas reales que se arriendan o en los propios de la ciudad digan.

14- Ítem si saben que algunos de los escribanos dichos estando suspensos de los dichos sus oficios los han usado sin tener recaudos bastante para ello haciendo autos judiciales y extrajudiciales examinando testigos y otorgando /folio 169v/ ante ellos escrituras públicas y otros recaudos digan.

15- Ítem de pública y notorio pública voz y fama digan lo que supieren.

Y habiendo visto este interrogatorio su merced el señor juez de residencia mandó que por su tenor se examinen a los testigos que declarasen en la pesquisa secreta encargándoles el secreto que corresponde. Así lo proveyó mandó y firmó en esta ciudad de Salta en siete días del mes de diciembre de mil setecientos sesenta y tres años de ello doy fe.

Balthazar Azebey

Ante mí

Don Joachín de la Cava

Escribano público y de cabildo de

Tarija y esta residencia

[A continuación se agrupan las declaraciones de los tes- tigos sobre los oficios examinados] 


\section{[...]}

[Interrogatorio sobre la actuación de los protectores de indios (Pieza 2, folios 202r-202v)]

Protectores de indios [arriba centrado].

Don Jacinto López Ver [margen izquierdo]

Por el tenor de este interrogatorio serán examinados los testigos que declarasen en la pesquisa secreta sobre los hechos y procedimientos de los protectores de naturales que obtuvieren dicho empleo en el tiempo que fue gobernador de ella el señor coronel don Juan Victorino Martínez de Tineo a saber.

1- Primeramente conocen al susodicho que administró dicho oficio, y si tienen noticia de esta residencia y generales de la ley digan.

2- Ítem si saben que dichos Protectores en los negocios graves y de importancia para hacer por los naturales han tomado concejo y parecer de letrados alegando y haciendo las cosas necesarias por su orden y parecer y si por no haberlo hecho ha venido algún daño y perjuicio a los indios digan.

3- Ítem si saben que siendo obligados los dichos Protectores a andar y favorecer a los indios que fueron reos no lo han hecho sino antes han favorecido y hecho por las partes que los perseguían digan.

4-Ítem si saben que los dichos Protectores supieron bien la lengua de los naturales. Y si por no saberla no los han defendido como están obligados por cuya causa les ha venido daño digan.

5- Ítem si saben que los dichos repartidores digo Protectores han llevado derechos dádivas y presentes de los /202v/ indios a quienes han ayudado en sus causas y a otros y sirviéndose de ellos teniéndolos ocupados en sus obras tratos y granjerías digan.

6- Ítem si todo lo que saben es público y notorio pública voz y fama digan.

Y habiendo visto este interrogatorio su merced el señor juez privativo de esta residencia mandó que por su tenor y forma declaren dichos testigos y se les encargue el sigilo. Así lo proveyó mandó y firmó en esta ciudad de Salta en siete días de diciembre de mil setecientos sesenta y tres años de ello doy fe.

Balthazar Azebey

Ante mí

Don Joachín de la Cava

Escribano público y de cabildo de

Tarija y esta residencia

[A continuación se agrupan las declaraciones de los testigos sobre los oficios examinados]

$[\ldots]$

[Interrogatorio sobre la actuación de los mayordomos de propios y de la ciudad (Pieza 2, folios 210r-210v)]

Mayordomos de la ciudad y de propios [arriba centrado].

Por el tenor de este interrogatorio serán examinados los testigos que declarasen en la pesquisa secreta sobre los hechos y procedimientos de los mayordomos de esta ciudad que son [...] [sigue lista de residenciados]. 
1- Primeramente si conocen los susodichos, que si los vieron ejercer dicho oficio, noticia de la residencia y generales de la ley digan.

2- Ítem si saben que dichos mayordomos las rentas que se han rematado de esta ciudad las han tomado para sí echando personas que las saquen.

3- Ítem si saben que dichos mayordomos hicieron buen tratamiento de los indios que de parte de la ciudad se les entrega para el bien y alivio de ella y si los ocuparon en las cosas tocantes al bien público o si se a provechaban de su trabajo personal en su individuo propio digan.

4- Ítem si saben que a dichos indios se les contribuía pagándoles lo que fuese por estatuto de esta ciu/folio210v/ dad o si lo dejaron de hacer digan.

5- Ítem de público y notorio pública voz y fama digan todo lo que supieren.

Y habiendo visto su merced el señor juez de esta residencia el interrogatorio de estas fojas dijo que a su tenor fuesen examinados encargándoles el sigilo que corresponde. Así lo proveyó mandó y firmó en esta ciudad de Salta en diez días del mes de diciembre de mil setecientos sesenta y tres años de ello doy fe.

Por mandado de su merced.

Balthazar Azebey

Don Joachín de la Cava

Escribano público y de cabildo de Tarija y esta residencia

[A continuación se agrupan las declaraciones de los testigos sobre los oficios examinados]

[...]

C- Declaraciones de testigos correspondientes a otras ciudades.

[Testimonio del Sargento mayor don Juan Antonio Sepúlveda (Pieza 3, folios 186r-188v), en el marco de la pesquisa secreta seguida contra los alcaldes ordinarios en la ciudad de Santiago del Estero]

Declaración del Sargento mayor don Juan Antonio Sepúlveda [margen izquierdo]

En dicha ciudad dicho día mes y año [24 de enero de 1764] yo el mencionado para el efecto de esta sumaria secreta mandé /folio 186v/ comparecer al Sargento mayor don Juan Antonio Sepúlveda quien hizo juramento de decir verdad celebrando según previene el derecho so cuyo cargó prometió decir lo que supiere y se le fuere preguntado y para ello anticipándole todos los requisitos para la inteligencia de lo que es llamado por el interrogatorio que es por cabeza fue examinado por él, y preguntado por la lista y en ella por el nombre de los sujetos que han sido alcaldes ordinarios en esta ciudad en el tiempo de esta residencia

1-dijo que los conocía y que sólo era comprendido en las generales de la ley de afinidad con el general don Juan Joseph Paz y con el Maestre de Campo don Francisco de Argañaraz y Murguía y que también los conocía al tiempo que ejercieron sus oficios pero que por ningún motivo de los que se comprenden en las generales de la ley faltará al hecho de la verdad y esto responde.

2- A la segunda pregunta dijo que lo que sabe es que el maestre de Campo Don Rodrigo López Caballero en el tiempo de dicha su alcaldía habiendo hecho llamar a un paragua y vecino de esta ciudad español noble de las primeras familias del Para /folio 187r/guay llamado Ignacio Davalos porque lo mandó a éste que fuese en seguimiento de una india que se le había huido al sargento mayor don Joseph de Frías vecino de esta ciudad que le parece que fue de este mencionado vecino y que como le respondiese que se hallaba sin caballos en que hacer dicha diligencia pero que lo solicitaría y que al otro día le hizo llamar y habiéndole respondido que no había hallado caballos, 
enfadándose dicho alcalde delante de mucha gente que se juntó a las voces del alcalde, le dio de garrotazos y acosado de ellos le agarró o quitó el bastón porque ya el dicho alcalde se lo había metido por la boca y aunque el alcalde le decía que soltase el bastón le dijo que no lo podía hacer porque con él estaba ofendiendo y que después de estos garrotazos como lo mandase prender el alcalde y no hallase por donde huirse el dicho Paraguay por la mucha gente que se había agolpado, se arrinconó a un rincón del patio del dicho alcalde y metió mano al cuchillo para / folio $187 \mathrm{v} /$ defenderse de los muchos que le acosaban y que habiéndole dicho uno de los pardos Orellanas que no tiene presente si fue Francisco o Vicente su hermano que se diese a prisión se dio el dicho Paraguay Davalos a él que mandó amarrar el dicho alcalde y después que lo tuvo asegurado le dio el dicho alcalde según el que declara oyó decir muchos garrotazos a los que decía dicho Paraguay que para qué le habían aconsejado que se diese a prisión si le habían de dejar maltratar de aquel modo y que de este modo atado lo trajeron a la cárcel acompañando siempre el mismo alcalde, indignado, maltratando al dicho Paraguay que le mandó poner dos pares de grillos, unos grandes de hombre y otros chicos de mujer, y que lo mandó poner en el cepo, teniéndolo en la cárcel mucho tiempo y que según ha oído decir le siguió causa y que los grillos pequeños se le enterraron en las carnes porque se le hincharon las piernas demasiadamente y que aunque hubo muchos empeños para que le quitase los dichos grillos nunca quiso hacerlo el sobre citado alcalde y que al acabo de mucho tiempo de estar en dicha prisión remaneció el dicho Paraguay refugiado en la Iglesia Matriz adonde se fue una cierta, que no sabe quien lo sacó de la cárcel /folio188r/ pero se presume que como entonces estuviese el alcalde de segundo voto don Antonio Garcia de Villegas retejando no se acuerda el que declara si eran las casas del cabildo o la dicha cárcel entre la peonada que tenía se escaparía y que el dicho alcalde de primer voto don Rodrigo lo mandó quitar el caballo ensillado y que quedó con todo el recado y herraje y que no sabe si después en algún tiempo se lo volvió que esto se podrá averiguar preguntándoselo a su viuda o hijos del dicho paraguay que esto es público y notorio y como tal se podrá hacer la averiguación y que de los demás alcaldes del tiempo de esta residencia no sabe cosa alguna sobre el asunto de la pregunta y responde.

3- A la tercera pregunta dijo que no sabe cosa alguna y esto responde.

4- A la cuarta pregunta dijo que no sabe lo que la pregunta y esto responde.

5- A la quinta pregunta dijo que no sabe en cuanto al contenido de la pregunta.

6- A la sexta pregunta dijo que ha oído decir que los dichos alcaldes han rondado y que también otras veces los ha visto pasar por su casa de ronda que de lo demás no ha oído cosa alguna este / folio $188 \mathrm{v} /$ declarante.

7-A la séptima pregunta dijo que no sabe nada de lo que la pregunta contiene y esto responde.

8- A la octava pregunta dijo que no sabe cosa alguna de lo que la pregunta contiene y esto responde.

9-A la novena pregunta dijo que no sabe otra cosa sobre este asunto sino que entonces había regidores y esto responde.

10-A la décima se le preguntó de público y notorio y dijo que sólo ha oído decir a excepción de lo que tiene dicho que han gobernado bien dichos alcaldes y que cuanto declarado tiene es la verdad de lo que sabe y pasa y habiéndosele leído dijo estar bien escrito que no tiene que añadir ni quitar que en él se afirma y ratifica que es de edad cuarenta y seis años poco más o menos y lo firmó conmigo dicho juez y testigos a la referida falta.

Francisco Ximenez de Paz

Juan Antonio Sepúlveda 
[juez subdelegado]

[declarante]

Testigo Antonio de Zuaznabar Testigo Francisco de Paz

[...]

[Testimonio del capitán don Juan de Zalazar (Pieza 4, folios101v-103r), en el marco de la pesquisa secreta seguida contra el gobernador y sus tenientes en la ciudad de La Rioja]

En la ciudad de La Rioja en veintiséis días del mes de enero de mil setecientos sesenta y cuatro. Para la suma ria y secreta pesquisa y en prosecución de ella mandé comparecer en este mi juzgado de Residencia al capitán don Juan de Zalazar vecino morador de esta dicha ciudad, a quien por ante mí y los testigos de dicha Residencia le recibí juramento, que lo hizo a Dios nuestro señor y una señal de cruz en forma de derecho so cargo del cual prometió decir la verdad, de lo que supiere y se le fuere preguntado, según tenor y forma del interrogatorio que está puesto por cabeza y de los demás que se subsiguen según la nómina de las personas que han de ser residenciadas que se le puso presente; si así lo hiciere Dios / folio 102r/ le ayude y de lo contrario se lo demande, y a la conclusión dijo así lo juro y amén con lo cual fuese- le preguntado si conoció y conoce al señor Coronel don Juan Victorino Martínez de Tineo Gobernador y Capitán General de esta provincia y su lugarteniente que lo fue de esta ciudad el general don Juan Bazán de Cabrera, demás ministros y oficiales y otras personas de los susodichos durante el tiempo que lo fueron.

$1^{\mathrm{a}}$ - Dijo a la primera que conoce y conoció al dicho señor Gobernador y su Lugarteniente que fue de esta ciudad y no otros ministros oficiales y personas durante el dicho tiempo y responde.

2-A la segunda fuesele preguntado si sabe que el dicho gobernador y su lugarteniente hayan dejado de cumplir algunas cartas, cédulas y provisiones, ordenanzas, instrucciones de su Majestad o de sus Gobernadores o los decretos que se hayan dado en favor de los indios de oficio o a pedimento de algún indio, declare en particular qué provisiones, o decretos, o en virtud de las instrucciones que se les dieron para el uso de dicho su oficio y en qué caso y si han remitido las dichas provisiones y de-cretos para que no haya efecto el cumplimiento de ellas. Dijo que no sabe lo que contiene la pregunta y responde.

3- A la tercera fuese le preguntado si sabe que el susodicho y su lugarteniente han residido el tiempo de su oficio en la dicha Provincia y repartimientos, y si estando ausentes dicho gobernador de su oficio ha llevado y cobra/folio102v/do su salario y que tanta cantidad. Dijo que no sabe y responde.

De manera que todas las preguntas desde la primera hasta la última se le fueron leídas y explicadas según y conforme su orden y concierto de palabra en palabra y enterado de ellas y su contexto con suficiente instrucción y entendídolas todas y cada una de ellas por sí, con más

lo que instruyen los títulos de dicho señor gobernador y su lugarteniente dijo que lo que tiene declarado es público y notorio pública voz y fama; y que en lo demás no sabe ni le consta ni ha oído decir lo que contienen las preguntas subsecuentes. Y habiéndosele leído su declaración, y nuevamente las demás preguntas según tenor y forma del interrogatorio citado dijo estar bien escrita que en ella no tiene que añadir ni quitar; porque en el juramento que hecho tiene se afirma y ratifica. $Y$ que para con dicho señor gobernador y lugarteniente no le tocan las generales de la ley. Y que es de edad de cuarenta y dos años poco más o menos. Y para que conste lo firmó conmigo y los testigos de Residencia /folio 103r/ a falta total de escribano de que doy fe.

Joseph Ambrosio Cansinos [juez subdelegado]

Juan de Salas [declarante] 
Testigo presente de residencia [a falta de escribano] Alonso Beresosa y Contreras

Testigo presente de residencia [a falta de escribano]

Juan Gonzalez Barroso

\section{$[\ldots]$}

[Testimonio del capitán don Juan de Reto (Pieza 5, folios 106v-107v), en el marco de la pesquisa secreta seguida contra el gobernador y sus tenientes en la ciudad de Tucumán]

Declaración de Juan Reto [margen izquierdo]

En la ciudad de San Miguel de Tucumán en tres días del mes de febrero de mil setecientos sesenta y cuatro años en pro /folio 107r/ secución de esta sumaria hice parecer ante mí al testigo declarante el capitán don Juan de Reto vecino de esta ciudad a quien recibí juramento por Dios nuestro Señor y una señal de cruz según derecho so cuyo gravamen prometió decir verdad de lo que supiere y le fuere preguntado y de guardar secreto, si así lo hiciere Dios le ayude y al contrario se lo demande y a la conclusión dijo sí juro y amén. Y habiéndole el interrogatorio a la

$1^{\text {a- }}$ - primera pregunta dijo que conoce al señor Coronel don Juan Victorino Martínez de Tineo y al teniente que fue de esta ciudad don Luis Joseph Díaz y que no le tocan las generales de la ley ni con los demás oficiales de ese tiempo, y que tiene noticia de esta residencia y responde.

$2^{\mathrm{a}}$ - A la segunda pregunta dijo que no sabe nada de lo que en ella se contiene.

3â-A la tercera pregunta dijo que le consta por oídas que el señor don Juan Victorino que fue gobernador en el tiempo de esta residencia se mantuvo todo el tiempo de su gobernación en la ciudad de Salta; y que en lo demás de la pregunta dijo que no sabe nada.

$4^{\mathrm{a}}$ - A la cuarta pregunta dijo que no sabe nada ni tiene presente por la distancia del tiempo hasta la undécima pregunta que responde.

$11^{\mathrm{a}}$ - que sabe por oídas pública voz y fama que su lugarteniente de dicho señor gobernador don Luis Joseph Díaz no tuvo la confirmación de la Real Audiencia para ejercer su empleo; y que oyó que en cabildo hubo algunas disenciones tocante a este punto, y sabe también por oídas era encomendero dicho teniente de algunas encomiendas; y que también sabe que es pública voz y fama lo que dice en esta pregunta.

$12^{\mathrm{a}}$-A la duodécima pregunta dijo que no sabe hasta la.

13á- décima tercia a la que responde que no ha llegado a su noticia haya visitado la provincia que cuando pasó por aquí a la ciudad de Salta recién que recibió Su Señoría de Gobernador y que no lo ha visto pasar por aquí más, ni sabe ni por oídas que haya salido de Salta y responde. /folio 107v/

14"-A la decimocuarta dijo que no sabe ni tiene presente como lleva dicho cosa alguna hasta la vigesimoquinta pregunta a la que responde que le consta por oídas que

25a - los más de los vecinos encomenderos sacan indios e indias de sus pueblos para su servicio, y que no sabe si las justicias lo disimulan o lo consienten y responde.

26a - A la vigesimosexta dijo que no sabe nada por la distancia del tiempo ni tiene presente tanto en esta pregunta como en las demás hasta la última y que por lo que tiene declarado es la pública voz y fama la verdad so cargo de su juramento en que se afirma y ratifica y leídosele su declaración dijo que no tiene que añadir ni quitar y que es de edad de cuarenta años más o menos y firmó conmigo y los testigos legales.

Juan de Reto [declarante]

Vicente Escobar [juez subdelegado] 
Testigo Juan Muñoz Tartalo

Testigo Gregorio

[a falta de escribano]

Laureano Valdez

[a falta de escribano]

$[\ldots]$

[Testimonio del Maestre de Campo don Simón Mercado y Reynoso (Pieza 6, folios 187r-188v), en el marco de la pesquisa secreta seguida contra el cabildo en la ciudad de Catamarca]

En la ciudad de San Fernando del Valle de Catamarca en veintitrés días del mes de enero de mil setecientos sesenta y cuatro yo dicho juez de residencia en prosecución de la sumaria información secreta que estoy recibiendo de don Simón Mercado y Reynoso, vecino de esta dicha ciudad, testigo llamado para este efecto, y en virtud del mismo juramento que hecho tiene de decir la verdad de todo lo que supiere y se le fuere preguntado, y de guardar sigilo, hasta la conclusión de esta causa le examiné por el tenor del interrogatorio contra el cabildo regidores y fieles ejecutores y demás que tienen voto en él y ejercieron sus oficios en el tiempo que fue gobernador Capitán General de esta provincia el señor Coronel de Infantería don Juan Victorino Martínez de Tineo enterado del dicho interrogatorio, de las personas y sus oficios,

1- a la primera dijo: que conocía a los regidores que habían sido en el tiempo de dicho señor coronel y sabe del uso de sus oficios y que en las generales de la ley no le toca ninguno de ellos, y que no han sido más que dos regidores en el dicho tiempo que lo fueron el sargento mayor don Andrés de Herrera, alférez real que fue en arrendamiento, y hoy en propiedad;/folio188v/y el sargento mayor don Francisco Xavier Román difunto regidor veinticuatro asimismo en arrendamiento.

2-A la segunda pregunta a dicho interrogatorio dijo que sabía, por público y notorio, pública voz y fama, no ha- cían los cabildos ordinarios a que estaban obligados en beneficio del bien común, sino muy de tarde en tarde y eso precisados, y esto se acuerda haberle oído quejarse, al dicho teniente que fue de esta ciudad, el general don Luis Joseph Díaz, pero que no se acuerda ni sabe porque causa se dejaban de hacer.

3-A la tercera pregunta dijo: que no sabe si habían hecho las mercedes de tierras, que contiene dicha pregunta.

4- A la cuarta pregunta dijo: que sabía que siempre habían hecho sus elecciones de oficios en personas de las fundadoras de esta ciudad, y suficientes.

5-A la quinta pregunta dijo: que no sabe que dichos regidos hayan hecho las ventas que contiene dicha pregunta, ni permitido que otros las hagan.

6- A la sexta pregunta dijo: que tampoco sabe nada de dicha pregunta.

7-A la séptima pregunta dijo: que no había oído decir, ni /folio 188r/ visto que dichos regidores, hubiesen hecho daño en los campos, y heredades de los vecinos; ni que les hayan hecho otros daños.

8- A la octava pregunta dijo; que no había conocido en aquel tiempo ni hasta el presente regidor fiel ejecutor alguno.

9-A la novena pregunta dijo: que tenía respondido sobre el oficio de fiel ejecutor, y que por lo que mira, a lo que se pregunta de los regidores, no ha sabido cosa alguna. 
10- A la décima pregunta dijo: que no sabe que hayan tenido en sus casas juegos prohibidos, ni consentidolos, a otras personas.

11-A la undécima pregunta dijo: que respecto de no haber habido fiel ejecutor en esta ciudad como lleva dicho, no había tenido noticia, de que se hubiesen ejecutado los puntos en dicha pregunta contenidos.

12- A la duodécima pregunta dijo: que por dicha falta de fiel ejecutor, los alcaldes ordinarios sabe, $\mathrm{y}$ ha visto hacen componer las calles, de esta ciudad, para las funciones de semana santa y no más. /folio 188v/

13- A la décima tercia pregunta dijo, que sabe por haberlo visto y que es público, y notorio, que dicho alférez real, saca el Real pendón cada año con acompañamiento de todo el vecindario de la ciudad y distrito, que para dicho efecto bajaban, y que ha sido con la veneración y el respeto debido.

14-A la décima cuarta pregunta dijo: que todo lo que lleva dicho, es por pública voz, y fama, y que esto es lo que sabe, y declara bajo del juramento que hecho tiene, en que se afirmó, y ratificó, y leidola su declaración dijo estar bien escrita, en la misma forma y manera, que había declarado, y que no tenía que quitar ni poner, que es de edad de setenta poco más o menos, como tiene dicho y para que conste lo firmó conmigo y los testigos nombrados para esta sumaria, a falta de escribano de que doy fe.

Santiago de Castro y Frías

[juez subdelegado]

Simón Mercado y Reynoso [declarante]

Testigo Francisco Antonio Barrera

[a falta de escribano]

Testigo don Pedro Joseph Escalante

[a falta de escribano]

\section{$[\ldots]$}

[Testimonio de don Antonio Suárez (Pieza 7, folios 177r-177v), en el marco de la pesquisa secreta seguida contra los alcaldes ordinarios en la ciudad de Jujuy]

Declaración de don Antonio Suárez [margen izquierdo]

En la ciudad de Jujuy en diez días del mes de enero de mil setecientos sesenta y cuatro años el juez de esta residencia mandé parecer ante en mi juzgado a don Antonio Suárez vecino de esta ciudad mayordomo de ella a quien le recibí juramento que lo hizo por Dios nuestro señor y por una señal de cruz según forma de derecho so cargo del cual prometió decir verdad de lo que supiere y fuere preguntado, y siéndolo al tenor del interrogatorio que el corresponda, y vista la nómina que al pie de él se halla dijo que conoce a los contenidos en ella sabe de esta residencia y no le tocan las generales de la ley, y esto responde.

$2^{a}, 3^{a}, 4^{a}$ y $5^{\text {a- }}$ - Desde la cuarta [sic] hasta la quinta pregunta /folio $177 \mathrm{v} /$ dijo que le parece han administrado bien justicia sin agravio de nadie ni llevar derechos algunos, ni dejar de castigar al que lo merecía ni otra cosa del tenor de ella, y responde.

$6^{\mathrm{a}}, 7^{\mathrm{a}}, 8^{\mathrm{a}}, 9^{\mathrm{a}}$ y $10^{\mathrm{a}}$ - De la sexta hasta la décima pregunta dijo que no sabe nada que decir contra estos residenciados bien lo que es así público y notorio, y es la verdad so cargo del juramento hecho en que se afirmó y ratificó, y que lo dirá de nuevo siempre que convenga, y leída su declaración dijo estar bien escrita, y lo firmó conmigo y los testigos dichos. 
Juan Bautista de Muruaga

Antonio Suárez

[juez subdelegado]

[declarante]

Pedo Joseph de Soto

Juan Joseph Morán

[a falta de escribano]

[a falta de escribano]

[Testimonio de don Antonio de Ayora (Pieza 8, folios 342vr-343r), en el marco de la pesquisa secreta seguida contra los alguaciles mayores y sus tenientes en la ciudad de Córdoba]

Declaración de don Antonio de Ayora [margen izquierdo]

En la ciudad de Córdoba a veintiocho días del mes de enero de mil setecientos sesenta y cuatro años: en conformidad del juramento que hecho tiene don Antonio de Ayora fue interrogado por el tenor de las preguntas contenidas en el interrogatorio perteneciente a los alguaciles mayores y sus tenientes.

$1^{\mathrm{a}-} \mathrm{Y}$ a la primera pregunta dijo: que conoce a las partes, tiene noticia de esta residencia, y que con ninguno le tocan las generales de la ley y responde.

$2^{\mathrm{a}}$ - A la segunda dijo: que no sabe lo que la pregunta contiene, y responde.

3-A la tercera dijo: que no sabe lo que la pregunta contiene, y responde.

$4^{\mathrm{a}}$ - A la cuarta dijo: que no sabe lo que la pregunta contiene, y responde.

$5^{\mathrm{a}}$ - A la quinta dijo: que no sabe lo que la pregunta contiene, y responde.

6'-A la sexta dijo: que no sabe lo que la pregunta contiene, /folio 343r/ y responde.

7ª-Alaséptimadijo:que no sabe lo que la pregunta contiene, y responde.

$8^{\mathrm{a}}$ - A la octava dijo: que no sabe lo que la pregunta con tiene, y responde.

9a-A la novena dijo: que no sabe lo que la pregunta contiene, y responde.

10â- A la décima dijo: que no sabe lo que la pregunta contiene, y responde.

11르- A la undécima dijo: que no sabe lo que la pregunta contiene, que sólo lo que de ella le consta es que dichos alguaciles mayores y sus tenientes han visitado las reales cárceles y prisiones, y responde.

12 $2^{\mathrm{a}}$ - A la segunda dijo: que no sabe lo que la pregunta contiene, y responde; que esta es la verdad de lo que sabe y para encargo del juramento que hecho tiene en que se afirma y ratifica que es de edad que lleva declarado, y lo firmó con su merced, de que yo el presente escribano doy fe.

Esteban de Montenegro

Antonio de Ayora

[juez subdelegado]

[declarante]

Ante mí

Celemente Guerrero 
Escribano público del número de Córdoba y de esta residencia

\section{BIBLIOGRAPHY}

Bascary, A. M. (1997). La saga de los Villafañe: una red familiar en el Tucumán Colonial. Andes, 8, 175-198.

Boixadós, R. (2004). Asuntos de familia, cuestiones de poder: la "concordia" en el Cabildo de La Rioja, Gobernación del Tucumán, 1708. Colonial Latin American Historical Review, 13 (2), 147-171.

Brading, D. (1990). La España de los Borbones y su Imperio Español. En L. Bethell (Ed.), Historia de América Latina 2. América Latina Colonial. Europa y América en los siglos XVI, XVII y XVIII (pp. 85-126). Barcelona : Editorial Crítica.

Bridikhina, E. (2007). Theatrum mundi. Entramados del poder en Charcas colonial. Bolivia: Instituto Francés de EstudiosAndinos / Plural Ediciones.

Cañeque, A. (2004). The king's living image: the culture and politics of viceregal power in Colonial Mexico. Nueva York: Routledge.

Curcio-Nagy, L. A. (2004). The great festivals of colonial Mexico City: performing power and identity. EEUU: University of New Mexico Press.

De la Orden Peracca, G. (2001). Familia y poder en Catamarca colonial. Los Nieva y Castilla (1630-1730). Memoria Americana, 10, 95-138.

García Valdeavellano, L. (1963). Las «Partidas» y los orígenes medievales del juicio de residencia. Boletín de la Real Academia de la Historia, t.153, cuaderno11, 205-246.

Geertz, C. (2000 [1981]). Negara. El Estado-teatro en el Bali del siglo XIX. Barcelona: Paidós.

González Alonso, B. (1978). El juicio de residencia en Castilla, I: origen y evolución hasta 1480. Anuario de historia del derecho español, 48, 193-247.

Guevara Gil, A. y Frank, S. (1994). A "personal visit": Colonial political ritual and the making of Indians in the Andes. Colonial Latin American Review, v.3 (1-2), 3-36.

Herzog, T. (1997). La presencia ausente: el virrey desde la perspectiva de las elites locales (Audiencia de Quito, 1670-1747). En P. Fernández Albaladejo (Coord.), Monarquía, imperio y pueblos en la España moderna, (pp. 819- 826). Alicante: Universidad de Alicante.

Herzog, T. (2000). Ritos de control, prácticas de negociación: pesquisas, visitas y residencias y las relaciones entre Quito y Madrid (1650-1750). Madrid: Fundación Histórica Tavera.

Jiménez Núñez, A. (1997). El juicio de residencia como fuente etnográfica: Francisco Briceño, gobernador de Guatemala (1565-1569). Revista Complutense de Historia de América, 23, 11-21.

Leach, E. (1976 [1954]). Sistemas políticos de la Alta Birmania. Estudio sobre la estructura social Kachin. Barcelona: Editorial Anagrama.

Lorandi, A. M. (2000). Las residencias frustradas. El juez Domingo de Irazusta contra el Cabildo de Salta. Andes, 11, 51-80. 
Lorandi, A. M. (2008). Poder central, poder local. Funcionarios borbónicos en el Tucumán colonial. Un estudio de antropología política. Buenos Aires: Prometeo.

Lorandi, A. M. y Smietniansky, S. (2004). La conspiración del silencio. Etnografía histórica de los cabildos del Tucumán colonial (1764-1769). Jahrbuch Für Geschichte Lateinamerikas, 41, 65-90.

Mariluz Urquijo, J. M. (1952). Ensayo sobre los Juicios de Residencia indianos. Sevilla: Escuela de Estudios Hispanoamericanos.

Marchionni, M. (2000). Acceso y permanencia de las elites en el poder político local. El cabildo de Salta a fines del período colonial. Cuaderno de la Facultad de Humanidades y Ciencias Sociales, 13, 283-306.

Mata de López, S. E. (2001). Familias de elite en Salta a fines de la colonia. Negocios y relaciones de poder. Memoria Americana, 10, 139-175.

O’Phelan Godoy, S. (1988). Un siglo de rebeliones anticoloniales. Perú y Bolivia 1700-1783. Cusco: Centro Bartolomé de las Casas.

Ortemberg, P. (2000). Celebraciones del poder real en Lima: itinerarios teórico-metodológicos. Memoria Americana, 9, 91-113.

Ortemberg, P. (2006). Teatro, jerarquía y potlatch: examen socio-histórico y antropológico de las entradas virreinales en Lima. Revista de Artes y Humanidades UNICA, 16, 13-34.

Osorio, A. (2008). Inventing Lima. Baroque Modernity in Peru's South Sea Metropolis. EEUU: Palgrave Macmillan.

Paz, G. L. (1997). Familia, linaje y red de parientes: la élite de Jujuy en el siglo XVIII. Andes, 8, 145-174.

Peirano, M. (2001). A análise antropológica de rituais. En M. Peirano (org.), o dito e o feito. Ensaios de antropología dos rituais (pp.17-40). Río de Janeiro: Relume Dumará.

Peirano, M. (2003). Rituais ontem e hoje. Brasil: Jorge Zahar.

Phelan, J. L. (1995). El Reino de Quito en el siglo XVII. Quito: Banco Central del Ecuador.

Pietschmann, H. (1996). Las Reformas Borbónicas y el sistema de intendencias en Nueva España. Un estudio político administrativo. México: FCE.

Ponce, M. (1985). El control de la gestión administrativa en el Juicio de Residencia al Gobernador Manuel González Torres de Navarra. Caracas, Academia Nacional de la Historia. Tomo I y Tomo II.

Ponce, M. y Vaccari de Venturini, L. (comp) (1980). Juicios de Residencia en la Provincia de Venezuela. Tomo II: Juan Pérez de Tolosa y Juan de Villegas. Caracas: Academia Nacional de la Historia.

Saguier, E. E. (1992). La lucha contra el nepotismo en los orígenes de las reformas borbónicas. La endogamia en los cabildos de Salta y Tucumán (1760-1790). Andes, (5).

Smietniansky, S. (2007). El juicio de residencia como ritual político en la colonia (Gobernación de Tucumán, siglo XVIII). Memoria Americana, 15, 71-101.

Smietniansky, S. (2009). La dimensión ritual del poder en el gobierno del Tucumán colonial (siglos XVII y XVIII). Un enfoque antropológico. Tesis de Maestría inédita. IDES / IDAES - UNSAM.

Smietniansky, S. (2010a). De preeminencias, estilos y costumbres: rituales y poder en loscabildos coloniales. Una aproximación etnográfica al análisis de materiales de archivo. Revista Colombiana de Antropología, 46 (2), 379-408. 
Smietniansky, S. (2010b). Tiempo y ritual. Una aproximación al análisis de las representaciones del orden en la sociedad colonial (Gobernación del Tucumán, siglos XVIIyXVIII). Revista del Museo de Antropología, 3, 99-112.

Smietniansky, S. (2010c). Celebrando el orden social, inquietando el orden ritual. Un análisis en clave ritual sobre usos, conflictos e intereses encontrados durante un juicio de residencia en el Tucumán colonial. Andes, (21), 187-221.

Tambiah,S.(1985).Culture, thought and social action. Cambridge: Harvard University Press.

Turner, V. (1999 [1967]). La selva de los símbolos. Aspectos del ritual ndembu. México: Siglo XXI.

Vaccari de Venturini, L. (1974). Evolución de los juicios de residencia en Venezuela (Siglos XVI-XVIII). Caracas: Academia Nacional de la Historia.

Vitar, B. (1997). Guerra y misiones en la frontera chaqueña del Tucumán (1700-1767). Madrid: Consejo Superior de Investigaciones Científicas.

\section{NOTES}

1. Cabe mencionar que, posteriormente, con el avance de la investigación ampliamos el universo institucional y extendimos el recorte temporal. Hoy día nuestra investigación aborda conjuntamente las instituciones del cabildo y los juicios de residencia en los siglos XVII y XVIII.

2. Distintos avances de la investigación quedaron plasmados en Smietniansky 2007, 2009, 2010a ,2010b y 2010c.

3. Ya reglamentado bajo la Pragmática de los Reyes Católicos, el juicio de residencia se trasladó a las Indias; posteriormente fue incorporado en la Leyes Nuevas de 1542-1543, además de verse regido por las reales cédulas, provisiones y acuerdos procedentes de la Corona. Finalmente en1681quedó contenido en la Recopilación de Leyes de Indias.

4. Sobre el proceso de configuración de las élites locales y su imbricación con las instituciones coloniales, para el caso de la gobernación del Tucumán, pueden consultarse los estudios de Bascary 1997, Boixadós 2004,De la Orden de Peracca 2001, Marchionni 2000, Paz 1997, Mata de López 2001 y Saguier 1992, entre otros.

5. En cuanto a las residencias, en esta perspectiva se sitúan los trabajos de Mariluz Urquijo (1952), García de Valdeavellano (1963), González Alonso (1978), Ponce (1985), Vaccari de Venturini (1974) y Ponce y Vaccari de Venturini (1980).

6. Jiménez Nuñez (1997). Agregamos en este núcleo un trabajo nuestro anterior (Lorandi y Smietniansky 2004), que si bien puede ser pensado bajo esa segunda categoría de estudios, no le cabe en su totalidad la crítica de Herzog. Por un lado, en esa ocasión analizamos los 'datos' contenidos en un juicio de residencia, pero por otro lado, al analizar los testimonios atendemos a cómo la estructura del juicio condicionaba la construcción de los mismos. En ese sentido, no presuponemos que la información registrada en el expediente sea neutral. Al mismo tiempo, tampoco concluimos que la residencia fuera un mecanismo eficaz de control.

7. Phelan (1995) y Lorandi (2000), para el caso de las residencias.

8. Véase los trabajos citados en nota 2.

9. La numeración de los ítems no se corresponde necesariamente con el listado previo.

10. AHN, Consejos, 20375, exp. 1, Pieza 8, f. 99r 


\section{ABSTRACTS}

The written record that we present constitutes an extract from the expedient elaborated during the juicio de residencia impeached to the governor of Tucumán Juan Victorino Martínez de Tineo in 1763-1764, preserved at the Archivo Histórico Nacional, in Madrid. This article contextualizes and accompanies its reading, and proposes an ethnographic approach based on the concept of ritual. For that, upon the transcribed document, we describe the typical celebration of a residencia and the way in which this royal proceeding has been studied. Considering this, we are particularly interested in presenting and pondering about the advantages and other dimensions that may be discovered through the analysis of residencia in terms of a ritual that constitutes a way of exercising power and contributes to the construction of colonial order. Here, the transcribed document constitutes a case to study and set an example of a different way to examine a given document.

El registro documental que presentamos constituye un extracto del expediente elaborado en el marco del juicio de residencia instruido al gobernador del Tucumán Juan Victorino Martínez de Tineo en 1763-1764, y que hoy se conserva en el Archivo Histórico Nacional de Madrid. Este artículo contextúa y acompaña la lectura del mismo, y propone una aproximación etnográfica centrada en el concepto de ritual. Para ello, a partir de la fuente transcripta, describimos en qué consistía la celebración de una residencia y de qué manera este procedimiento regio de control ha sido estudiado. Visto este panorama, en particular interesa exponer y reflexionar sobre las ventajas y otras facetas que nos permite descubrir el análisis de la residencia considerada en términos de un ritual a través del cual se ejercía el poder y cuya celebración aportaba a la construcción del orden colonial. En ese recorrido la fuente transcripta se constituye en un caso para pensar y ejemplificar en qué consiste esa otra forma de interrogar y examinar un mismo corpus documental.

\section{INDEX}

Keywords: juicio de residencia, colonial government institutions, ritual, province of Tucumán Palabras claves: juicio de residencia, instituciones del gobierno colonial, ritual, gobernación del Tucumán

\section{AUTHOR}

\section{SILVINA SMIETNIANSKY}

Centro de Estudios de Historia, Cultura y Memoria - Universidad Nacional de Quilmes - Consejo Nacional de Investigaciones Científicas y Técnicas/ Universidad de Buenos Aires.

Correo electrónico: silvismieti@yahoo.com.ar 